\title{
Flora das cangas da Serra dos Carajás, Pará, Brasil: Apocynaceae
}

\author{
Flora of the canga of Serra dos Carajás, Pará, Brazil: Apocynaceae
}

\author{
Géssica Elaine Azevedo Fernandes ${ }^{1,5}$, Nara Furtado de Oliveira Mota ${ }^{2,3}$ \& André Olmos Simões ${ }^{1,4}$
}

\begin{abstract}
Resumo
Este estudo apresenta um tratamento das espécies de Apocynaceae registradas nas cangas da Serra dos Carajás, Pará. São apresentadas descrições detalhadas, chaves para identificação dos gêneros e espécies, ilustrações, dados sobre distribuição geográfica e comentários morfológicos e ecológicos das espécies tratadas. Foram registradas 22 espécies e 13 gêneros na área de estudo. Destacam-se as espécies de Marsdenia bergii e Matelea microphylla, endêmica das cangas da Serra dos Carajás, e Marsdenia thomasii, com apenas duas coletas, uma para o estado do Mato Grosso e a outra para a região de Carajás.
\end{abstract}

Palavras-chave: Asclepiadoideae, Apocynoideae, canga, FLONA Carajás, espécies endêmicas.

\begin{abstract}
This study presents a treatment of the species of Apocynaceae from the canga of the Serra dos Carajás, Pará. Detailed descriptions, keys for identification of genera and species, illustrations, data on geographic distribution, and morphological and ecological comments of the treated species are presented. Twenty two species and 13 genera were registered in the study area. The two species of Marsdenia and one of Matelea are particulary interesting. Marsdenia bergii and Matelea microphylla are endemic to the canga of Serra dos Carajás whereas Marsdenia thomasii is known only from two collections, one from Mato Grosso state and the other from the Carajás region.
\end{abstract}

Key words: Asclepiadoideae, Apocynoideae, canga, FLONA Carajás, endemic species.

\begin{abstract}
Apocynaceae
Apocynaceae Juss. s.l. possui ca. de 375 gêneros e 5000 espécies (Endress 2004) distribuídas em cinco subfamílias (Endress et al. 2014). As espécies podem ser reconhecidas pela presença de látex, folhas geralmente opostas com coléteres na base ou ao longo da nervura central e no pecíolo (intra e interpeciolares), anteras adnatas ou não a cabeça do estilete formando um ginostégio e ápice do gineceu modificado em uma cabeça do estilete bastante desenvolvida (Endress \& Bruyns 2000; Endress et al. 2014). As subfamílias Rauvolfioideae e Apocynoideae não apresentam polínias; diferenciam-se pelas anteras totalmente férteis, com o dorso não lignificado as tecas ocupando toda a sua extensão longitudinal, e não adnatas ao gineceu em Rauvolfioideae, e anteras parcialmente férteis com o dorso lignificado e as tecas ocupando apenas parte
\end{abstract}

de sua extensão longitudinal, e adnatas ao gineceu formando ginostégio, em Apocynoideae (Endress \& Bruyns 2000; Endress 2004). As subfamílias Periplocoideae, Secamonoideae (que não possuem distribuição no Brasil) e Asclepiadoideae, por sua vez, apresentam pólen agregado em polínias, diferenciando-se pela estrutura do translator e pelo número de microsporângios. Em Periplocoideae, o translator tem forma de colher, aderindo-se ao polinizador por meio de um disco adesivo, e as anteras são tetrasporangiadas. Em Secamonoideae e Asclepiadoideae, o translator se adere ao polinizador por um mecanismo semelhante a um clipe e são diferenciadas pelos números de polínias aderidas ao translator, quatro e duas advindas de anteras tetra e bisporangiadas, respectivamente (Endress \& Bruyns 2000). A família possui uma grande diversidade de frutos podendo variar de

\footnotetext{
${ }^{1}$ Universidade Federal Rural da Amazônia/Museu Paraense Emílio Goeldi - MPEG, Campus Pesquisa, Prog. Pós-graduação em Ciências Biológicas, Botânica Tropical, Av. Perimetral 1901, Terra Firme, 66077-530, Belém, PA, Brasil

${ }^{2}$ Museu Paraense Emílio Goeldi, Coord. Botânica, Prog. Capacitação Institucional, Av. Perimetral 1901, Terra Firme, 66077-830, Belém, PA, Brasil.

${ }^{3}$ Instituto Tecnológico Vale de Desenvolvimento Sustentável, R. Boaventura da Silva 955, 66055-090, Belém, PA, Brasil.

${ }^{4}$ Universidade Estadual de Campinas, Inst. Biologia, Prog. Pós-graduação em Biologia Vegetal, 13083-970, Campinas, SP, Brazil. aosimoes@unicamp.br

${ }^{5}$ Autor para correspondência: gessica.eaf@gmail.com
} 
folicários (termo utilizado por Spjut (1994) para os frutos de Asclepiadaceae e Apocynaceae, derivados de um gineceu esquizocárpico com ovários unidos somente por estiletes ou estigmas), secos ou carnosos, cápsulas, moniliformes, drupas e bagas. As sementes também apresentam variaçnao, podendo ser nuas, aladas, comosas ou ariladas (Matozinhos \& Konno 2008). Geralmente os frutos são gêmeos ou solitários pelo aborto de um dos carpelos, com variação morfológica entre as espécies (Gomes 2008).

Sua distribuição é cosmopolita (Mabberley 2008; Pereira et al. 2016), com cerca de 756 espécies, ocorrendo em todos os domínios fitogeográficos brasileiros. Nas cangas da Serra dos Carajás a família está representada por cinco gêneros e oito espécies para a subfamília Apocynoideae, cinco gêneros e seis espécies para subfamília Asclepiadoideae, e três gêneros e oito espécies para a subfamília Rauvolfioideae. Destas, Marsdenia bergii Morillo e Matelea microphylla Morillo são endêmicas das cangas da Serra dos Carajás e Marsdenia thomasii Morillo possui registro de apenas duas coletas, sendo uma para o estado do Mato Grosso e a outra para a região da Serra dos Carajás.

\section{Chave de identificação dos gêneros de Apocynaceae ocorrentes nas cangas da Serra dos Carajás.}

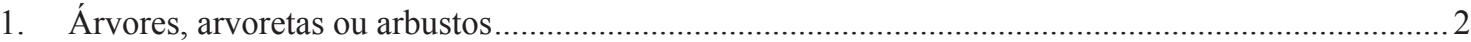

2. Folhas alternas; fruto do tipo folicário, achatado............................................... 2. Aspidosperma

2'. Folhas opostas; fruto folicário ou bacáceo, quando folicário nunca achatado.............................. 3

3. Árvore até $9 \mathrm{~m}$ alt.; corola tubulosa; fruto baga; sementes nuas ...................... 6. Lacmellea

3'. Arvoretas ou arbustos 1-5 m alt.; corola hipocrateriforme; fruto folicário; sementes ariladas 13. Tabernaemontana

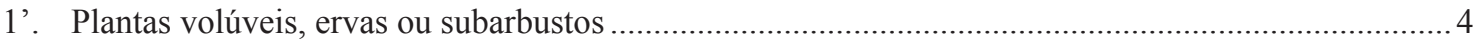

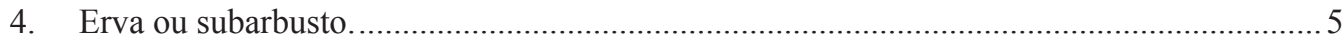

5. Erva; corola com lobos reflexos; ginostégio estipitado................................. Asclepias

5'. Subarbusto ereto; corola com lobos eretos; ginostégio não estipitado .... 5. Hemipogon

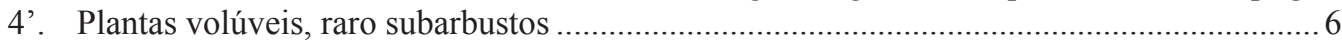

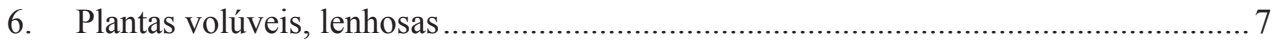

7. Domácias, quando presentes, na axila das nervuras secundárias com a nervura primária da lâmina foliar; folicários sempre 2, dispostos horizontalmente

4. Forsteronia

7'. Domácias ausentes; folicários 2 ou 1 por aborto ou cápsulas, pendentes ............. 8

8. Ramos sulcados

10. Odontadenia

8'. Ramos cilíndricos

9. Lenticelas presentes; corola hipocrateriforme, sem polínias.

12. Secondatia

9'. Lenticelas ausentes; corola rotácea, com polínias eretas

8. Marsdenia

6'. Plantas volúveis ou subarbustos, não lenhosas ........................................................... 10

10. Coléteres foliares ausentes .............................................................11. Prestonia

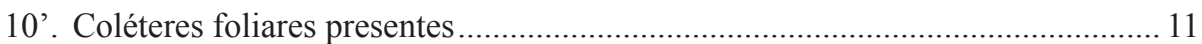

11. Inflorescências racemosas; corola infundibuliforme ou hipocrateriforme; polinários ausentes 7. Mandevilla

11'. Inflorescências cimosas; corola rotácea; polinários presentes 12

12. Corona intraestaminal, cimbiforme; folicários lisos ...... 3. Blepharodon

12'. Corona interestaminal, triangular; folicários aristados longitudinalmente

9. Matelea

\section{Asclepias L.}

Ervas ou subarbustos eretos. Látex branco.

Ramos cilíndricos sem lenticelas. Folhas opostas, com coléteres na face adaxial e na base da nervura principal. Inflorescências do tipo cimeiras umbeliformes, terminais ou subaxilares; sépalas eretas, com coléteres alternos na base; corola rotácea, lobos reflexos; corona simples, segmentos 
livres entre si, cuculados, com um calcar curvado sobre o ginostégio. Ginostégio estipitado; apêndice membranáceo apical das anteras orbicular ou suborbicular; retináculo menor que as polínias, geralmente sagitiforme; caudículas oblíquodescendentes, desprovidas de membrana reticulada e inseridas na parte apical das polínias, polínias achatadas lateralmente, férteis em toda a sua extensão; apêndice estilar geralmente plano; ovário ovoide, glabro. Folicários fusiformes, lisos ou estriados; sementes comosas e verrucosas.

Asclepias possui distribuição cosmopolita. No Brasil, o gênero ocorre em todos os domínios fitogeográficos e é representado por seis espécies, sendo quatro endêmicas (BFG 2015). Na Serra dos Carajás, o gênero está representado por uma espécie.

\subsection{Asclepias curassavica L., Sp. Pl. 1:215. 1753.}

Fig. 1a-b

Erva, 50-60 cm alt. Ramos glabros, com coléteres intrapeciolares. Folhas com pecíolo $1-8 \mathrm{~mm}$ compr.; lâmina $6,5-11,6 \times 0,8-3,3 \mathrm{~cm}$, estreito-oblonga, ápice agudo a atenuado, base atenuada a assimétrica, margens inteiras, glabras. Inflorescências 6-10-floras, 5-9,2 cm compr.; pedúnculo 35-55 mm compr., glabro; brácteas lanceoladas. Flores com pedicelo 7-17 mm compr., lanoso; sépalas 3-4 × ca. $1 \mathrm{~mm}$, estreitooblongas, lanosas; corola vermelha, tubo $0,5-0,8$ mm compr., glabro, lobos 5,8-7 × 2,4-3,7 mm, oblongos ou ovados, glabros; corona com lobos $2,5-5,2 \times 1-2,7 \mathrm{~mm}$ compr., mais longos que as anteras; ginostégio $4-5 \mathrm{~mm}$ alt.; anteras ca. $2 \mathrm{~mm}$ compr., quadrangulares, asas mais longas que o dorso; retináculo ca. $0,25 \times 0,21 \mathrm{~mm}$, subsagitado, mais curto que as polínias, caudículas ca. $0,5 \mathrm{~mm}$ compr., oblíquo-descendentes, geniculadas, com membrana hialina reduzida ou vestigial, polínias $0,9-1,08 \times 0,28-0,39 \mathrm{~mm}$, clavadas, levemente falciformes; apêndice estilar reduzido a uma cabeça deprimida côncava ou plana; ovário ovoide, glabro. Folicários 3-5×4-8 cm, glabros; sementes não vistas.

Material selecionado: Canaã dos Carajás, Serra Sul, S11D, 06 22'35"S, 50²1'20"W, 681 m, 3.XII.2015, fl., C.S. Nunes et al. 86 (MG). Parauapebas, Serra Norte, N5, 31.X.1985, R. Secco \& O. Cardoso 696 (MG).

Asclepias curassavica é uma espécie ruderal encontrada principalmente em ambientes antropizados (Matozinhos \& Konno 2011). Diferese das demais espécies pela sua corola rotácea com lobos reflexos, ginostégio estipitado e corona cuculada. Possui ampla distribuição mundial, com provável origem na África (BFG 2015). No Brasil ocorre nas regiões: Norte (AC, AM, AP, PA), Nordeste (AL, BA, CE, MA, PE, PI, RN, SE), Centro-Oeste (DF, GO, MS, MT), Sudeste (ES, MG, RJ, SP), Sul (PR, RS, SC) (BFG 2015). Na Serra dos Carajás: Serra Norte: N5 e Serra Sul: S11D. Encontrada em área de transição e canga aberta, florescendo nos meses de maio a outubro.

\section{Aspidosperma Mart. \& Zucc.}

Árvores a arbustos, látex branco. Ramos com lenticelas, coléteres nodais ausentes. Folhas alternas, raramente opostas ou verticiladas; nervação broquidródoma a craspedódroma. Inflorescências do tipo dicásios modificados corimbiformes; sépalas sem coléteres internamente na base; corola tubular; ginostégio ausente; estames não adnatos a cabeça do estilete; cabeça do estilete fusiforme a globosa; ovário súpero, apocárpico. Folicários 2, raro 1 por aborto, achatados, falciformes, dolabriformes, piriformes ou suborbiculares, geralmente lenhosos; sementes aladas.

O gênero possui ampla distribuição na região neotropical. No Brasil, é representado por 42 espécies ocorrendo em todos os domínios fitogeográficos (BFG 2015). Na Serra dos Carajás, está representado por três espécies.

\section{Chave de identificação das espécies de Aspidosperma das cangas da Serra dos Carajás}

1. Inflorescência terminal; corola esverdeada; folicários pubescentes

2.1. Aspidosperma brasiliense

1'. Inflorescência axilar; corola branca a amarela; folicários glabros

2. Corola amarela, lobos contorcidos, eretos; folicários 3,3 × 1,7 cm ....

2.2. Aspidosperma multiflorum

2'. Corola branca, lobos não contorcidos, reflexos; folicários $7 \times 3 \mathrm{~cm}$

2.3. Aspidosperma subincanum 


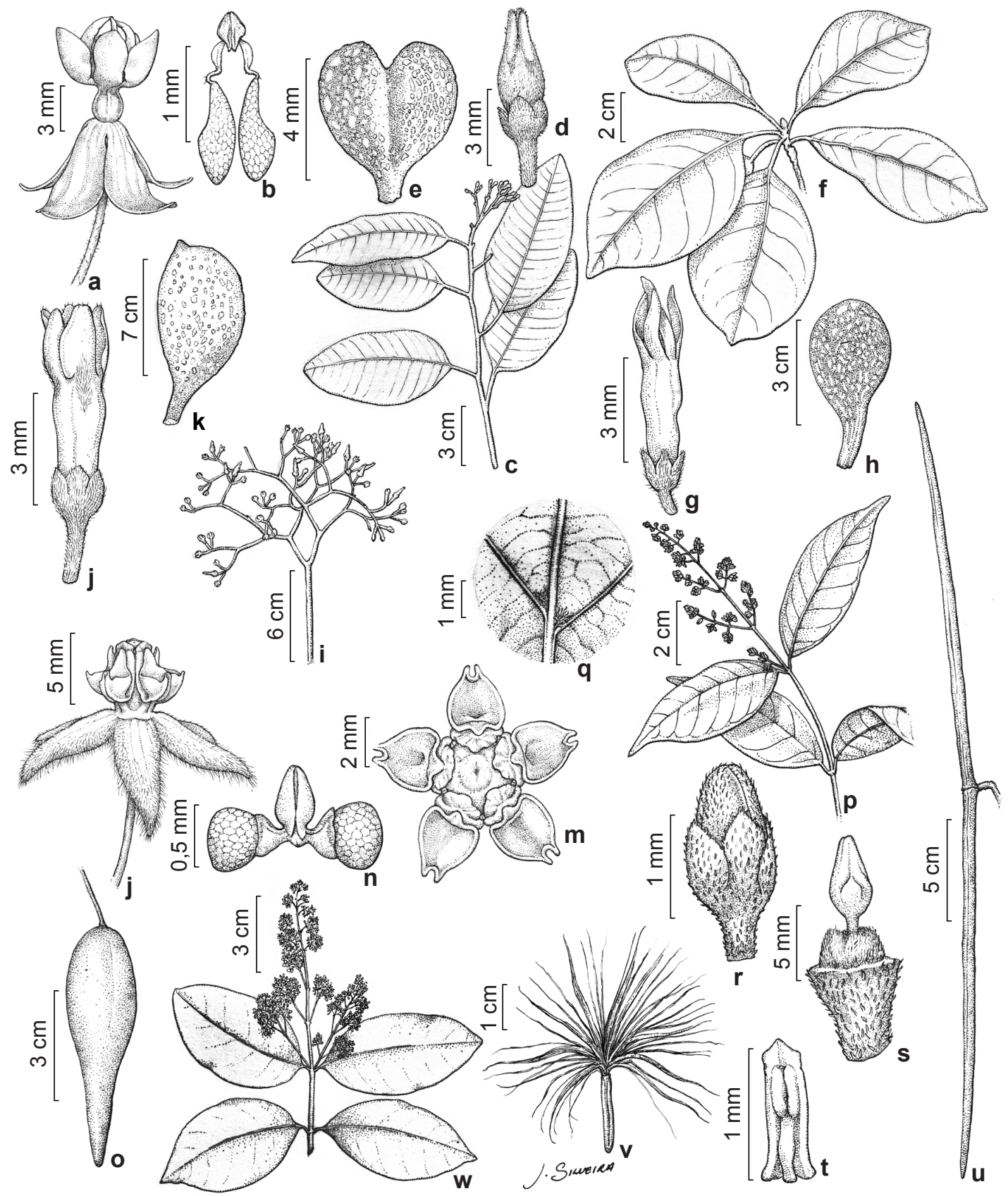

Figura 1 - a-b. Asclepias curassavica - a. flor em vista lateral; b. polinário. c-e. Aspidosperma brasiliense - c. ramo florífero; d. flor em vista lateral; e. fruto. f-h. Aspidosperma multiflorum -f. ramo vegetativo; $\mathrm{g}$. flor vista lateral; h. fruto. i-k. Aspidosperma subincanum $-\mathrm{i}$. inflorescência; $\mathrm{j}$. flor em vista lateral; $\mathrm{k}$. fruto. 1-o. Blepharodon pictum -1 . flor vista lateral; $\mathrm{m}$. ginostégio vista frontal; n. polinário; o. fruto. p-v. Forsteronia affinis - p. ramo florífero; q. detalhe das domácias na nervura da folha; r. botão floral; s. gineceu; t. estame; u. semente; v. fruto. w. Forsteronia sp - ramo florífero. (a-b. Secco 696; c-e. Ribeiro 1387, Silva 19; f-h. Silva 1039; i-k. Silva 1045, Silva 909; 1-o. Giorni 195; Mota 1127; p-v. Costa 509, Fernandes 59; w. Viana 4353).

Figure 1 - a-b. Asclepias curassavica - a. flower in side view; b. pollinaria. c-e. Aspidosperma brasiliense - c. flowering branch; $d$. flower in side view; e. fruit. f-h. Aspidosperma multiflorum - $\mathrm{f}$. vegetative branch; g. flower in side view; $\mathrm{h}$. fruit. i-k. Aspidosperma subincanum -i. inflorescence; $\mathrm{j}$. flower in side view; $\mathrm{k}$. fruit. 1-o Blepharodon pictum - 1 . lower in side view; $\mathrm{m}$. gynostegium in frontal view; $n$. pollinaria; 0 . fruit. $\mathrm{p}$-v Forsteronia affinis - p. flowering branch; q. detail of the domatia next to the leaf vein; r. flower bud; s. style head; t. stamen; u. seed; v. fruit. w. Forsteronia $s p$ - flowering branch. (a-b. Secco 696; c-e. Ribeiro 1387, Silva 19; f-h. Silva 1039; i-k. Silva 1045, Silva 909; 1-o. Giorni 195; Mota 1127; p-v. Costa 509, Fernandes 59; w. Viana 4353). 
2.1. Aspidosperma brasiliense A.S.S. Pereira \& A.C.D. Castello, Phytotaxa 326(4): 236. 2017.

Fig. 1c-e

Árvore 1,8-8 m alt. Ramos cilíndricos, pilosos a glabrescentes. Folhas com pecíolo 7-10 mm compr.; lâmina 4,7-8,3 × 1,4-4 cm, oblonga a estreito-elíptica, ápice atenuado a arredondado, base obtusa a assimétrica, margens inteiras. Inflorescências terminais, ca. 23-floras, ca. 3,3 cm compr.; pedúnculo ca. $7 \mathrm{~mm}$ compr., pubescente; brácteas elípticas. Flores com pedicelo ca. $2 \mathrm{~mm}$ compr., pubescente; sépalas ca. $1 \mathrm{~mm}$ compr., ovais, pubescentes; corola esverdeada, tubo ca. $4 \mathrm{~mm}$ compr., lobos ca. $2 \mathrm{~mm}$ compr., imbricados, suberetos a patentes, pubescentes, ovais. Folicários ca. 4 $\times 3 \mathrm{~cm}$, achatados, obovados, com lenticelas, pubescentes; sementes não vistas.

Material selecionado: Canaã dos Carajás, Mina do Sossego, 627'32"S, 5004'25"W, $710 \mathrm{~m}$, 25.XI.2009, fl., R.D. Ribeiro et al. 1387 (MG); Serra Sul, Corpo C, 6024'11"S, 502'31"W, 649 m, 30.VI.2010, fl., A.J. Arruda et al. 295 (BHCB).

Aspidosperma brasiliense assemelha-se às demais espécies do gênero encontradas em Carajás principalmente pela sua corola tubular e folicários obovais e achatados, porém difere pela presença de flores pequenas (tudo da corola ca. $4 \mathrm{~mm}$ compr e lobos ca. $2 \mathrm{~mm}$ compr.), com lobos da corola imbricados e patentes.

Endêmica do Brasil ocorre nas regiões: Norte (PA, TO), Nordeste (BA, CE, MA, RN, AL), Centro-Oeste (GO, DF, MT) e Sudeste (MG, RJ, SP) (BFG 2015). Na Serra dos Carajás: Serra Sul: S11C e Mina do Sossego. Encontrada em área de transição mata baixa e canga aberta. Floresce nos meses de setembro a novembro.

\subsection{Aspidosperma multiflorum A. DC., Prodr.} 8: 397.1844.

Fig. $1 \mathrm{f}-\mathrm{h}$

Árvore 4-8 m alt. Ramos cilíndricos, sulcados, glabros. Folhas com pecíolo ca. $10 \times$ 20 mm compr.; lâmina 5-10 × 3-4,5 cm, elíptica a obovada, ápice agudo, base atenuada, pilosa a glabrescente, margens inteiras. Inflorescências axilares, multifloras, 2-6 cm compr.; pedúnculo 8-22 mm, glabrescente. Flores com pedicelo 0,5-2 mm, glabrescente; sépalas ca. $1 \mathrm{~mm}$ compr., ovais, pilosas; corola amarela, tubo 1-5 mm compr., lobos 1-2,5 mm compr., glabrescentes, contorcidos, estreito-elípticos, eretos; anteras ca. 0,5 mm compr., cordadas, ápice atenuado, base cordada, glabras; ovário globoso, piloso; estilete ca. $1 \mathrm{~mm}$; cabeça do estilete ca. $0,1 \mathrm{~mm}$ compr., urceolada, pilosa. Folicários ca. $3,3 \times 1,7 \mathrm{~cm}$, obovados, com lenticelas, glabros; sementes não vistas.

Material selecionado: Canaã dos Carajás, Serra Sul, S11D, 23.VII.2015, fl. e fr., D.F. Silva et al. 1039 (HCJS).

Aspidosperma multiflorum assemelha-se a outra espécie da área de estudo, A. subicanum, principalmente pela sua inflorescência axilar multiflora. No entanto, $A$. multiflorum apresenta flores maiores ( $\geq 5 \mathrm{~mm}$ vs. $\leq 4 \mathrm{~mm}$ compr.), com lobos contorcidos (vs. reflexos) e folicários menores (ca. $3,3 \times 1,7 \mathrm{~cm}$ vs. ca. $7 \times 3 \mathrm{~cm}$ ).

Espécie endêmica do Brasil. Ocorre nas Regiões: Norte (PA, RO), Nordeste (BA, CE, MA, PB, PE, PI), Centro-Oeste (DF, GO, MS, MT), Sudeste (MG, SP) (BFG 2015). Na Serra dos Carajás: Serra sul: S11D. Encontrada em área de transição da mata baixa para a canga aberta, florescendo e frutificando no mês de julho.

\subsection{Aspidosperma subincanum Mart. ex} A.DC., Prodr. 8: 397. 1844 Fig. 1i-k Árvore ca. $5 \mathrm{~m}$ alt. Ramos cilíndricos, pilosos. Folhas com pecíolo 5-20 mm compr.; lâmina $15-18 \times 7-8 \mathrm{~cm}$, elíptica a obovada, ápice atenuado, base cuneada, margens inteiras, pilosas na face abaxial. Inflorescências axilares, multifloras, 6,5-7,5 cm compr.; pedúnculo 3-15 $\mathrm{mm}$ compr., piloso. Flores com pedicelo ca. 1,5 $\mathrm{mm}$ compr., piloso; sépalas ca. $1 \mathrm{~mm}$, ovais, pilosas; corola branca, tubo ca. 2-3 mm compr., lobos ca. $1 \mathrm{~mm}$ compr., glabrescentes, oblongos, reflexos; anteras ca. 0,5 mm compr., cordadas, ápice agudo, base cordada, glabras; estilete ca. $0,7 \mathrm{~mm}$ compr.; cabeça do estilete ca. $0,1 \mathrm{~mm}$ compr., fusiforme; ovário globoso, tomentoso. Folicários ca. $7 \times 3 \mathrm{~cm}$, achatados, obovados, com lenticelas, glabros; sementes não vistas.

Material selecionado: Canaã dos Carajás, Serra Sul, S11D, 23.VII.2015, fr., D.F. Silva 1045 (HCJS); A $3 \mathrm{~km}$ do Bairro Planalto, área de pastagem, 06'24'30.6”'S, 4952'21.4”'W, 9 m, 15.VI.2013, fl., D.F. Silva 909 (HCJS).

Para afinidades e comentários morfológicos, ver espécie Aspidosperma multiflorum.

No Brasil, ocorre nas regiões: Norte (PA, TO), Nordeste (BA, CE, MA, PI, SE), CentroOeste (DF, GO, MS, MT), Sudeste (ES, MG, RJ, SP), Sul (PR, SC) (BFG 2015). Na Serra dos Carajás: Serra Sul: S11D. Coletada em área de transição da mata para a canga, florescendo no mês de junho e frutificando no mês de julho. 

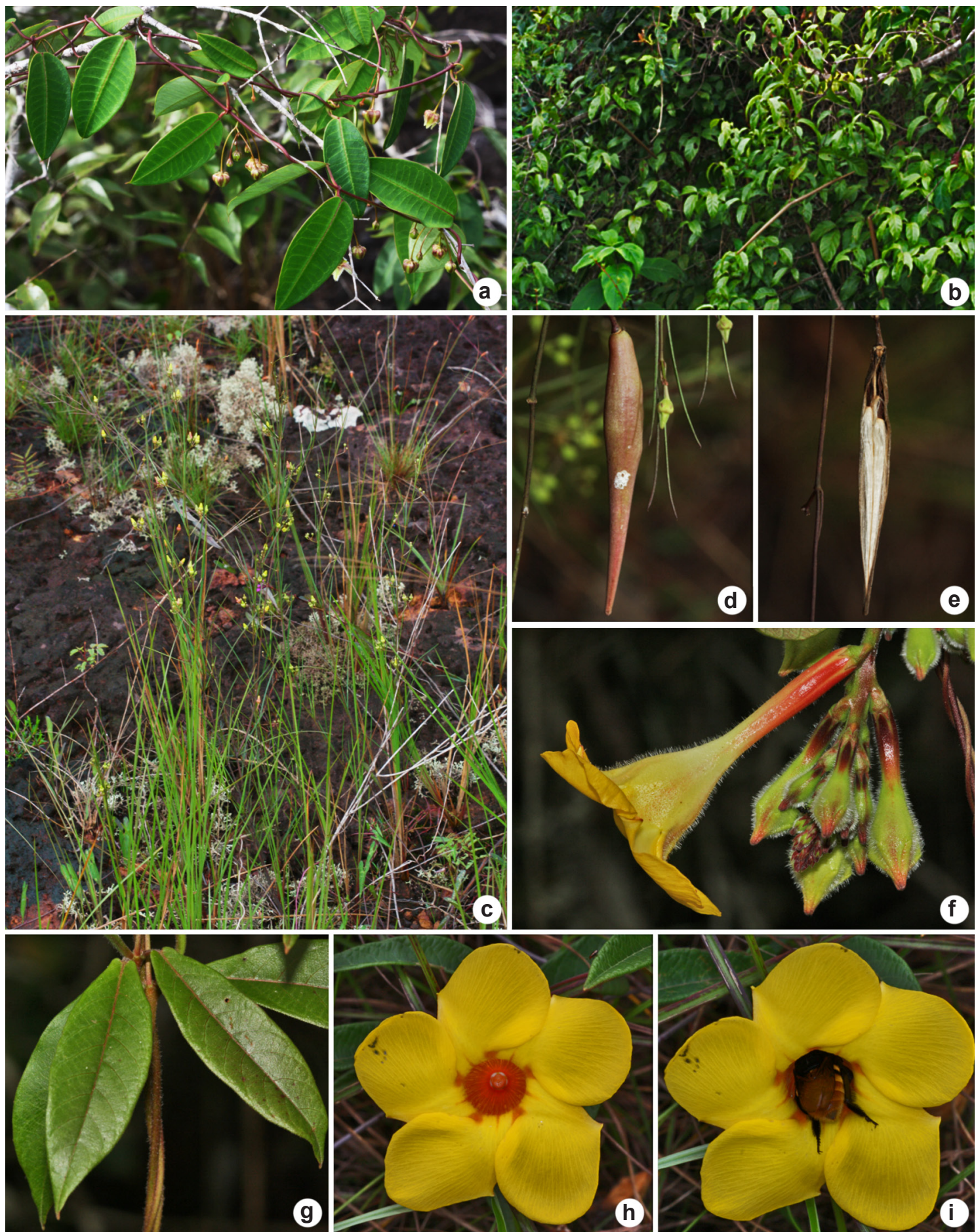

Figura 2 - a. Blepharodon pictum - a. hábito. b. Forsteronia affinis - b. hábito. c-e. Hemipogon sprucei - c. hábito; d. fruto; e. fruto aberto com sementes. f-i. Mandevilla scabra - f. flor em vista lateral; g. lâmina foliar; h. flor em vista frontal; i. flor com a presença de visitante floral. (Fotos: André O. Simões).

Figure 2 - a. Blepharodon pictum - a. habit. b. Forsteronia affinis - b. habit. c-e. Hemipogon spruce - c. habit; d. fruit; e. open fruit showing seeds. f-i. Mandevilla scabra - f. flower in side view; g. leaf blade; h. flower in frontal view; i. Flower with floral visitor. (Photos: André O. Simões). 


\section{Blepharodon Decne.}

Plantas volúveis, látex branco. Ramos glabros. Folhas opostas, pecioladas, com coléteres na base da nervura principal na face adaxial. Inflorescências do tipo cimeiras tirsiformes, subaxilares. pediceladas; sépalas com coléteres opostos; corola rotácea, lobos patentes; corona simples, segmentos livres, cimbiformes, intraestaminais; ginostégio séssil; apêndice membranáceo apical das anteras suborbiculares; retináculo maior ou menor que as polínias, caudículas horizontais, providas de membrana reticulada, polínias férteis em toda a sua extensão; apêndice estilar mamilado. Folicários fusiformes, lisos; sementes comosas.

O gênero possui distribuição neotropical, da América Central ao norte da Argentina. No Brasil está representado por treze espécies, ocorrendo em todos os domínios fitogeográficos (BFG 2015). Na Serra dos Carajás está representado por uma espécie.

\subsection{Blepharodon pictum (Vahl) W.D. Stevens, Novon} 10(3): 242. 2000.

Figs. 11-o; 2a

Planta volúvel. Ramos cilíndricos, sem lenticelas, com coléteres interpeciolares. Folhas com pecíolo 5-18 mm compr.; lâmina 13-67 × 4-26 mm, oblonga a elíptica, ápice mucronado a acuminado, base truncada a subcordada, margem inteira, com um par de coléteres na base. Inflorescências tirsiformes, 5-12-floras, 2-3,5 $\mathrm{cm}$; pedúnculo 3-8 mm, glabro; brácteas lanceoladas. Flores com pedicelos 5-18 mm, com coléteres na base, glabros; sépalas 2-4 × ca. $2 \mathrm{~mm}$, ovadas, papilosas, com coléteres alternos na base; corola esverdeada, tubo ca. $4 \times 2 \mathrm{~mm}$, lobos ca. $10 \times 4 \mathrm{~mm}$, patentes, face abaxial glabra, face adaxial papilosa a pubérula, ovados; corona simples, segmentos creme, 3,5-4 $\times 2,5-3 \mathrm{~mm}$, cimbiformes, parte interna adnata ao dorso das anteras, parte externa inteira e fechada até o ápice; ginostégio séssil, ca. $5 \mathrm{~mm}$; anteras ca. $4 \mathrm{~mm}$, sub-retangulares, asas bem mais longas que o dorso, apêndice $0,5 \mathrm{~mm}$, suborbicular; retináculo ca. $0,35 \times$ $0,2 \mathrm{~mm}$, ovoide, caudículas $0,18-0,23 \mathrm{~mm}$ compr., horizontais, providas de membrana reticulada, polínias ca. $0,33 \times 0,23 \mathrm{~mm}$, pendentes, piriformes, paralelas; apêndice estilar plano; ovário ovoide, glabro. Folicários 6-7 × 1,3-1,5 cm, lisos, glabros; sementes, 5-3 mm compr., comosas.
Material selecionado: Canaã dos Carajás, Serra Sul, S11A, 20.II.2017, fl., G.E.A. Fernandes et al. 88 (MG); Corpo A, B e C, 6020'43"S, 50²4'29'W, 8.XII.2007, fl. e fr., N.F.O. Mota et al. 1127 (BHCB); S11D, 6023' 1'S, 5023'10'W, 16.III.2009, fl., V.T. Giorni et al. 195 (BHCB). Marabá [Parauapebas], Serra Norte, N1, 18.IV.1970, fl. e fr., $P$. Cavalcante \& M. Silva 2658 (MG); N4, 17.III.1984, fl., A.S.L. da Silva et al. 1863 (MG).

Em sua forma vegetativa, Blepharodon pictum pode ser facilmente confundida com B. bicuspidatum, ocorrente no estado do Pará, mas não em Carajás, diferenciando-se daquela espécie pelas flores maiores e polínias ovoides e oblongas, com comprimento e largura visivelmente distintos (Rapini 2010). Diferese das demais espécies de Apocynaceae das cangas de Carajás pela corola rotácea esverdeada e a corona cimbiforme.

Espécie com distribuição na América do Sul. No Brasil ocorre nas regiões: Norte (AC, AM, AP, PA, RO, RR, TO), Nordeste (AL, BA, CE, MA, PB, PE, RN, SE), Centro-Oeste (DF, GO, MS, MT), Sudeste (ES, MG, RJ, SP) e Sul (PR) (BFG 2015). $\mathrm{Na}$ Serra dos Carajás é registrada para a Serra Norte: N1 e para a Serra Sul: S11A, S11B, S11C, S11D. Coletada nas áreas de canga aberta, florescendo dos meses de fevereiro a dezembro e frutificando nos meses de dezembro e abril.

\section{Forsteronia G. Mey.}

Plantas volúveis, látex branco. Ramos cilíndricos, glabrescentes, com lenticelas e coléteres nodais. Folhas opostas, raro verticiladas usualmente com domácias pubescentes nas axilas da nervura primária, com coléteres na base. Inflorescências tirsiformes, multifloras; sépalas iguais, com coléteres alternos ou opostos; corola rotácea, pré-floração dextrorsa; ginostégio presente; estames inclusos a exclusos, adnatos ao gineceu; cabeça do estilete fusiforme; ovário apocárpico; piloso no ápice. Folicários 2; sementes comosas.

O gênero possui ampla distribuição nos neotrópicos. No Brasil, está representado por 24 espécies, ocorrendo nos domínios fitogeográficos da Amazônia, Caatinga, Cerrado e Mata Atlântica (BFG 2015). Na Serra dos Carajás está representado por duas espécies.

\section{Chave de identificação das espécies de Forsteronia das cangas da Serra dos Carajás}

1. Lâmina foliar com um par de coléteres na base e domácias na axila das nervuras secundárias com a nervura primária; inflorescências terminais .... 4.1. Forsteronia affinis

1'. Lâmina foliar sem coléteres e domácias; inflorescências axilares 4.2. Forsteronia sp. 


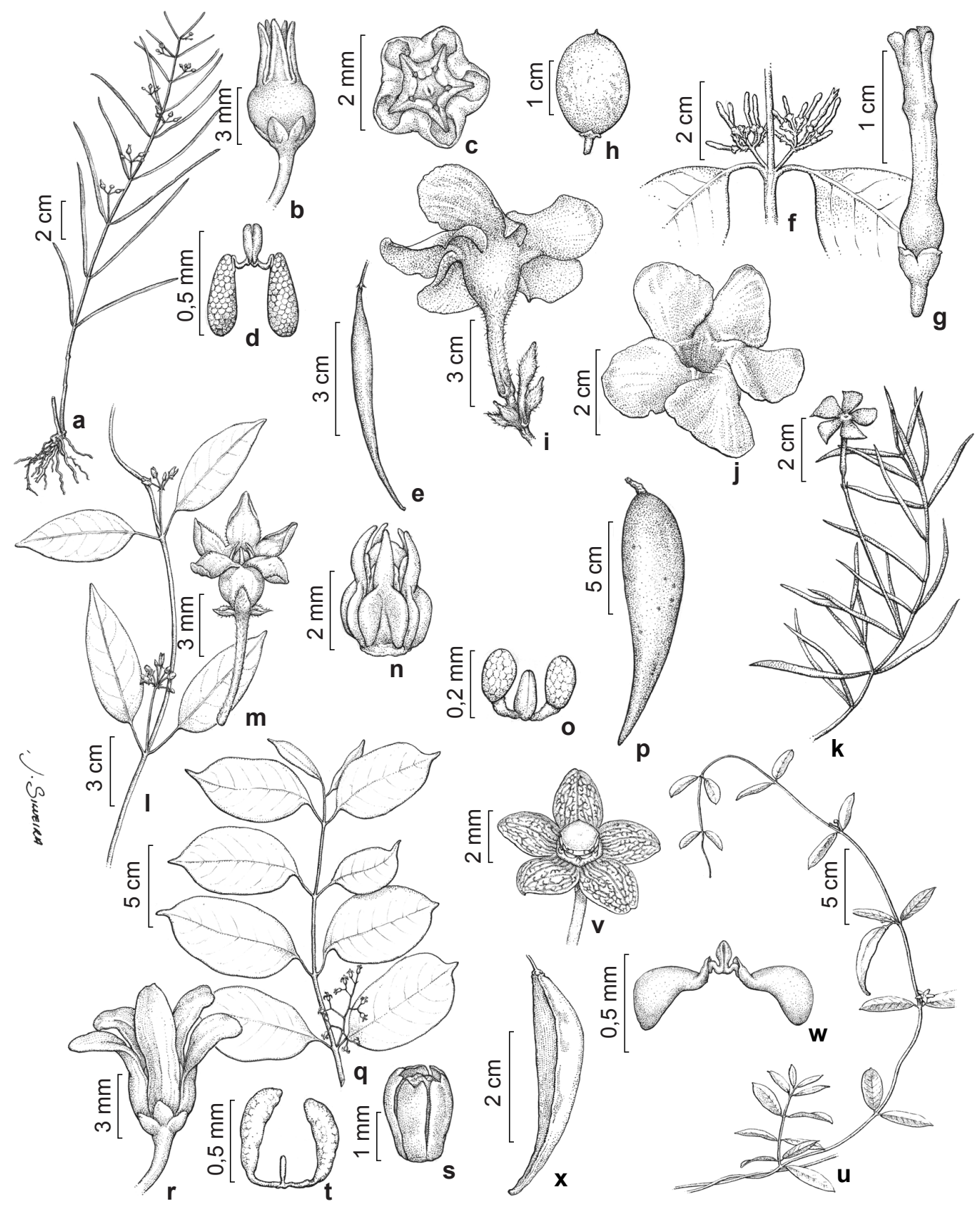

Figura 3 - a-e. Hemipogon sprucei - a. hábito; b. flor vista lateral; c. ginostégio vista frontal mostrando a corona; d. polinário; e. fruto. f-h. Lacmellea arborenses - f. inflorescência; g. flor em vista lateral; h. fruto. i-j. Mandevilla scabra - i. flor em vista lateral; j. flor em vista frontal. k. Mandevilla tenuifolia - hábito. 1-p. Marsdenia bergii-1. hábito; $\mathrm{m}$. flor vista lateral; $\mathrm{n}$. ginostégio e corona; o. polinário; p. fruto. q-t. Marsdenia thomasii - q. ramo florífero; r. flor vista lateral; s. ginostégio vista lateral mostrando a corona; t. polinário. u-x. Matelea microphylla - u. hábito; v. flor evidenciando o ginostégio; w. polinário; x. fruto arestado (a-e. Fernandes 44; f-h. Silva 3001, Lobato 4107; i-j. Rocha 94; k. Fernandes 86; 1-p. Costa 577; Fernandes 77; q-t. Silva 142-A; u-x. Falcão 559). Figure 3 - a-e Hemipogon spruce - a. habit; b. flower in side view; c. gynostegium in frontal view depicting the corona; d. pollinaria; e. fruit. f-h Lacmellea arborescents - f. inflorescence; g. flower in side view; h. fruit. i-j. Mandevilla scabra - i. flower in side view; j. flower in frontal view. $\mathrm{k}$. Mandevilla tenuifolia - habit. 1-p. Marsdenia bergii - 1. habit; $\mathrm{m}$. flower in side view; $\mathrm{n}$. gynostegium with corona; o. pollinaria; $\mathrm{p}$. fruit. q-t. Marsdenia thomasii - q. flowering branch; r. flower in side view; s. gynostegium in side view, depicting the corona; t. pollinaria. u-x. Matelea microphylla - u. habit; v. flower evidencing the gynostegium; w. pollinaria; x. ribbed fruit (a-e. Fernandes 44; f-h. Silva 3001, Lobato 4107; i-j. Rocha 94; k. Fernandes 86; 1-p. Costa 577; Fernandes 77; q-t. Silva 142-A; u-x. Falcão 559). 
4.1. Forsteronia affinis Mull. Arg., Fl. bras. 6(1): 100, pl. 30. 1860.

Figs. 1p-v; 2b

Planta volúvel, lenhosa. Folhas com pecíolo 2-7 mm compr.; lâmina 3,3-10 × 1-6 cm, elíptica, ápice atenuado a acuminado, base subcordada, margem inteira, glabras, com par de coléteres na base e domácias na axila da nervura central da face abaxial; nervuras secundárias impressas. Inflorescências terminais, 3-15-floras, 4,2-7,2 $\mathrm{cm}$; pedúnculo 1,2-3,2 cm, piloso; brácteas ovais. Flores com pedicelo 1-7 mm, piloso; sépalas ca. $0,8 \mathrm{~mm}$ compr., pilosas, ovais, coléteres opostos; corola creme, ca. $1 \mathrm{~mm}$ compr., ereta, oblonga, lobos ca. $0,5 \mathrm{~mm}$, pilosos, obovados; anteras ca. $0,8 \mathrm{~mm}$ compr., sagitadas, ápice cuspidado, base cordada, pilosas; ovário piriforme, piloso; estilete ca. $0,3 \mathrm{~mm}$ compr.; cabeça do estilete ca. 0,5 $\mathrm{mm}$ compr.; disco nectarífero 5-lobado na base do ovário. Folicário 5-21,3 × 1-2,5 cm, glabro, lenhoso; sementes elípticas.

Material selecionado: Canaã dos Carajás, Serra Sul, S11D, 622'23"S, 50²1'09'W, 729 m, 3.XII.2015, fl., A.O. Simões et al. 1809 (MG). Marabá [Parauapebas], Serra Norte, N1, 18.II.2017, fr., G.E.A. Fernandes 59 (MG).

Forsteronia affinis difere-se das demais espécies na área de estudo principalmente pela presença de domácias na axila da nervura central de suas folhas, nervuras impressas na lâmina foliar, base subcordada, coléteres na base da lâmina foliar, inflorescência terminal e coléteres calicinais opostos.

Espécie com ampla distribuição, principalmente na área de drenagem do rio Amazonas. Colômbia, Venezuela, Peru e Mato Grosso do Sul e Pará (Hansen 1985). No Brasil ocorre nas regiões: Norte (AC, AM, PA, RO) e Centro-Oeste (MT) (BFG 2015). Serra dos Carajás: Serra Norte: N1 e Serra Sul: S11D. Encontrada em área de transição, florescendo no mês de Dezembro e frutificando no mês de fevereiro.

\subsection{Forsteronia sp.}

Fig. 1w

Planta volúvel, lenhosa. Folhas com pecíolo 2-4 mm compr.; lâmina 5,3-9,5 × 3-5 cm, elíptica, ápice atenuado a agudo, base atenuada, margem inteira, glabras, com coléteres e domácias ausentes; nervuras secundárias emersas e pouco visíveis. Inflorescências axilares, 11-35-floras, 6,5-12,5 $\mathrm{cm}$; pedúnculo 5-8 $\mathrm{mm}$ compr., glabro, brácteas ovais. Flores com pedicelo $3-14 \mathrm{~mm}$, piloso; sépalas ca. $0,8 \times 0,5 \mathrm{~mm}$, ovais, pilosas, com coléteres calicinais alternos; corola creme, $0,2-3$ $\times 0,8-1,4 \mathrm{~mm}$, tubo ca. $2 \mathrm{~mm}$ compr., lobos ca. 1 $\mathrm{mm}$ compr., eretos, oblongos; anteras ca. $1,7 \mathrm{~mm}$ compr., ápice atenuado, base cordada, pilosas; ovário piriforme, piloso, estilete ca. $0,8 \mathrm{~mm}$ compr.; cabeça do estilete ca. $1 \mathrm{~mm}$ compr; disco nectarífero lobado. Frutos e sementes não vistos.

Material selecionado: Canaã dos Carajás, Serra Sul, S11D, 6024'23"S, 50¹8'10”'W, 650 m, 2.X.2009, fl., P.L. Viana et al. 4353 (MG).

Forsteronia sp. assemelha-se a $F$. affinis pois ambas apresentam inflorescência tirsiforme e flores menores que $2 \mathrm{~mm}$, pilosas. Entretanto, difere-se desta por apresentar inflorescência axilar, ausência de domácias e coléteres na lâmina foliar, nervuras não impressas, base da lamina foliar atenuada e coléteres calicinais alternos enquanto que $F$. affinis apresenta coléteres na base da lâmina foliar e coléteres calicinais opostos. A precisa determinação desta espécie não foi possível pela ausência de coletas com frutos e sementes e por não se encaixar perfeitamente na descrição das demais espécies do gênero. A espécie ocorre na Serra dos Carajás: Serra Sul: S11D. Encontrada em área de transição entre mata baixa para a canga aberta.

\section{Hemipogon Decne.}

Subarbustos eretos ou plantas volúveis, látex branco. Ramos cilíndricos, pubescentes. Folhas opostas, sésseis. Inflorescências cimeiras umbeliformes, subaxilares ou axilares, pedunculadas; sépalas com coléteres alternos; corola urceolada, lobos eretos no ápice; corona reduzida a uma prega soldada ao tubo da corola. Ginostégio séssil; apêndice membranáceo apical das anteras oval-lanceolado, lóculos situados ao longo do ginostégio; retináculo menor que as polínias, caudículas horizontais, providas ou não de membrana reticulada, inseridas no terço superior das polínias, polínias férteis em toda a sua extensão; apêndice estilar mamilado ou apiculado. Folicários 2; sementes comosas.

Gênero neotropical distribuído na América do Sul no Peru, Bolívia, Paraguai e Brasil (FontellaPereira et al. 2014). No Brasil são registradas 11 espécies com distribuição para quase todos os estados (BFG 2015). Na Serra dos Carajás é representado por apenas uma espécie.

5.1. Hemipogon sprucei E. Fourn., Fl. bras. 6(4): 197. 1885.

Figs. 2c-e; 3a-e

Subarbusto ereto a volúvel. Ramos sem lenticelas, com coletéres interpeciolares. Folhas sesseis; lâmina 10-67 × 0,7-1 mm, lineares, ápice agudo, base atenuada, margem espinosa. Inflorescência 3-5-flora, 20-26 mm, pedúnculo 

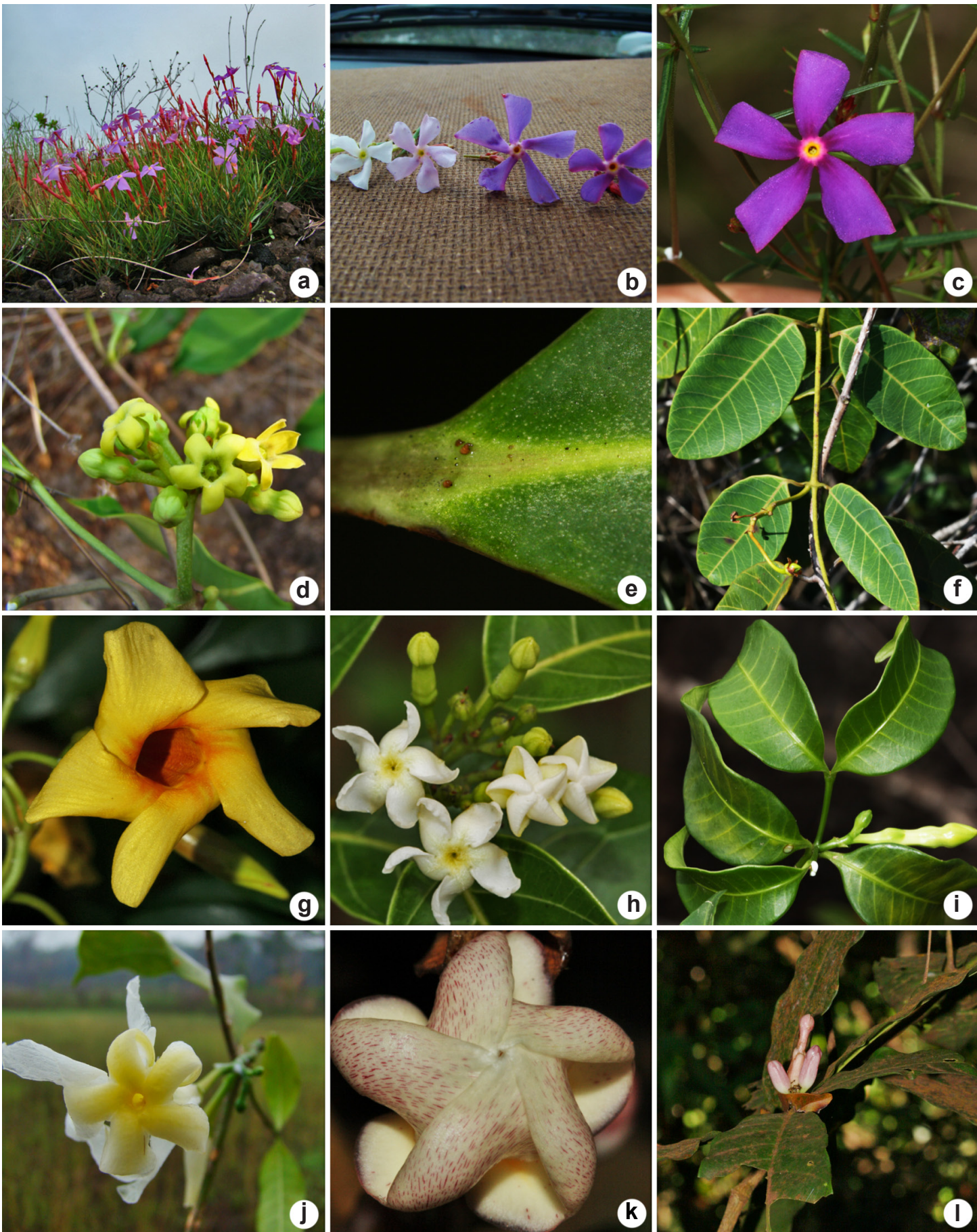

Figura 4-a-c. Mandevilla tenuifolia - a. hábito; b. variação de cores e tamanhos na flor; c. flor em vista frontal. d-e. Marsdenia bergii - d. inflorescência; e. detalhe de coléteres na base da lâmina. f-g. Odontadenia nitida - f. ramo florífero; g. flor em vista frontal. h. Secondatia desinflora - inflorescência. i-j. Tabernaemontana flavicans - i. ramo com flor; j. flor em vista frontal. k-1. Tabernaemontana macrocalyx - k. flor em vista frontal; 1. ramo com inflorescência (Fotos: a-b, j. Nara F.O.Mota; c, e-i, k-1. André O. Simões e d. Pedro L. Viana).

Figure 4-a-c. Mandevilla tenuifolia - a. habit; b. color and size variation in flower; c. flower in frontal view. d-e. Marsdenia bergii-d. inflorescence; e. detail of the colleters at the base of the leaf blade. f-g. Odontadenia nitida $-\mathrm{f}$. flowering branch; g. flower in frontal view. h. Secondatia densiflora - inflorescence. i-j. Tabernaemontana flavicans - i. Flowering branch; j. flower in frontal view. k-1. Tabernaemontana macrocalyx - $\mathrm{k}$. flower in frontal view; 1. branch with inflorescence (Photos: a-b, j. Nara F.O.Mota; c, e-i, k-1. André O. Simões and d. Pedro L. Viana). 
5-20 mm, glabro, brácteas lanceoladas. Flores com pedicelo 2-5 mm, glabro; sépalas $1-2 \times 1-1,2 \mathrm{~mm}$, ovais; corola, esverdeada, tubo 1,2-3 × 1-3 mm, lobos 1-4 × 0,6-1 mm, papilosos adaxialmente, estreitotriangulares; corona simples, ca. 0,9 mm compr., subglobosa, trilobada; ginostégio ca. $0,8 \mathrm{~mm}$; anteras ca. 0,6 mm compr., trapezoides, apêndice da antera ca. $0,1 \mathrm{~mm}$ compr., retuso; retináculo ca. $0,1 \times 0,05 \mathrm{~mm}$, oblongo, caudículas ca. 0,07 mm, polínias ca. $0,3 \times$ 0,1 mm, oblongas; apêndice estilar apiculado; ovário ovoide, glabro. Folicário 3,3-6 × 2-4 cm; sementes ca. $4 \times 2$ mm compr., comosas.

Material selecionado: Canaã dos Carajás, Serra Sul, S11A, 6¹8'57'S, 50²6'43"W, 737 m, 21.III.2012, fl., A.J. Arruda et al. 752 (BHCB); S11D, 6²3'32"S, $50^{\circ} 22^{\prime} 6$ "W, 700 m, 24.I.2012, fl., L.V.C. Silva et al. 1078 (BHCB). Parauapebas, Serra Norte, N1, 11.I.2017, fl. e fr., G.E.A. Fernandes 7 (MG); N3, 13.III.1985, fl. e fr., R.S. Secco 425 (MG); N4, 20.III.1984, fl. e fr., A.S.L. da Silva et al. 1919 (MG); N5, 603'S, 50² ' 'W, $650 \mathrm{~m}$, 16.V.1982, fl. e fr., C.R. Sperling et al. 5718 (MG); N6, 17.II.2017, fl. e fr., G.E.A. Fernandes et al. 44 (MG).

Hemipogon sprucei difere-se das outras espécies de Apocynaceae das cangas de Carajás pelo seu hábito subarbustivo ereto e flores urceoladas com lobos eretos e abaxialmente papilosos.

É endêmica do Brasil, ocorrendo nas regiões Norte (AM, PA) e Centro-Oeste (GO, MS, MT) (BFG 2015). Na Serra dos Carajás: Serra Norte: N1, N3, N4, N5 e N6 e Serra Sul: S11A, S11D. Espécie encontrada em área de canga aberta e solo rochoso, florescendo e frutificando nos meses de dezembro a maio.

\section{Lacmellea H. Karst.}

Árvores, látex branco. Ramos cilíndricos, glabros coleteres ausentes. Folhas opostas, glabras a puberulentas, pecioladas. Inflorescências cimosas, axilares, pauci a multifloras. Sépalas, com ou sem coléteres na base; corola hipocrateriforme, creme, branca ou amarelada, ginostégio ausente; estames inclusos; cabeça do estilete cilíndrica ou fusiforme; ovário sincárpico. Frutos bagas; sementes nuas.

Lacmellea é um gênero neotropical, com 22 espécies (Morales 2007). No Brasil são registradas 12 espécies com distribuição para quase todos os estados (BFG 2015). Na Serra dos Carajás é representado por apenas uma espécie.

6.1. Lacmellea arborescens (Mull. Arg.) Markgr., Notizbl. Bot. Gart. Berlin-Dahlem 15: 626. 1941.

Fig. $3 f-h$

Árvore, ca. $9 \mathrm{~m}$. Ramos cilíndricos, sem lenticelas, com coléteres intrapeciolares. Folhas com pecíolo 4-12 mm compr.; lâmina 5,7-11,5 × 2-4,8 $\mathrm{cm}$, oval a elíptica, ápice atenuado a cuspidado, base cuneada a atenuada, margem inteira. Inflorescências 3-11-floras, 23-30 mm compr.; pedúnculo 3-9 mm compr., pubescente; brácteas deltoides, com coléteres na base. Flores com pedicelo 2-7 mm, glabro; sépalas ca. $1 \times 2 \mathrm{~mm}$, ovais, glabras, com coléteres alternos; corola amarela ou creme, glabra, tubo inferior 4-12 $\times 1-4 \mathrm{~mm}$, tubo superior 2-6 × 1-3 mm, lobos ca. $2 \times 1 \mathrm{~mm}$, eretos, glabros, arredondados; anteras ca. $4 \mathrm{~mm}$ compr., sagitadas, ápice agudo, base sagitada, glabras; ovário ovoide, glabro, estilete ca. $1 \mathrm{~mm}$ compr.; cabeça do estilete estreito-elíptica, 2-3 mm. Baga 3-1,5 cm, glabra; semente elipsoide, ca. $10 \times$ $5 \mathrm{~mm}$, glabra.

Material selecionado: Canaã dos Carajás, Serra da Bocaina, 618'51"S, 49041'6”W, 717 m, 19.XII.2010, fr., N.F.O. Mota et al. 2004 (MG; BHCB). Parauapebas, N1, 2.IV.1977, fr., M.G. Silva \& R. Bahia 3001 (MG).

Lacmellea arborescens difere-se das demais espécies ocorrentes na área de estudo principalmente pelos frutos bacoides e inflorescências axilares. Espécie com distribuição amazônica. No Brasil, ocorre nas regiões: Norte (AM, PA, RO, RR), Centro-Oeste (MT) (BFG 2015). Na Serra dos Carajás ocorre na área de transição da mata baixa para a canga aberta na Serra Norte: N1 e na Serra da Bocaina, com flores no mês de novembro e frutos nos meses de outubro a abril.

\section{Mandevilla Lindl.}

Plantas volúveis ou subarbustos, látex branco. Ramos cilíndricos com coléteres nodais. Folhas opostas com presença de coléteres na base ou ao longo da nervura principal. Inflorescências terminais ou axilares, racemosas, com brácteas; sépalas iguais a subiguais, com coléteres alternos, opostos ou contínuos; corola infudibuliforme ou hipocrateriforme, pré-floração dextrorsa; ginostégio presente; estames inclusos, adnatos ao gineceu; cabeça do estilete umbraculiforme com 5 projeções longitudinais em toda sua extensão; ovário apocárpico. Folicários 2, geralmente fundidos no ápice; sementes comosas.

O gênero é neotropical, com cerca de 150 espécies distribuídas do sudoeste dos Estados Unidos à Argentina em uma grande variedade de habitats como os desertos, savanas, campos e florestas (Woodson 1933; Sales 1993; Kock \& Kinoshita 1999; Simões et al. 2006; Morokawa et al. 2013). No Brasil são registradas 66 espécies com ampla distribuição (BFG 2015). Na Serra dos Carajás está representado por duas espécies. 


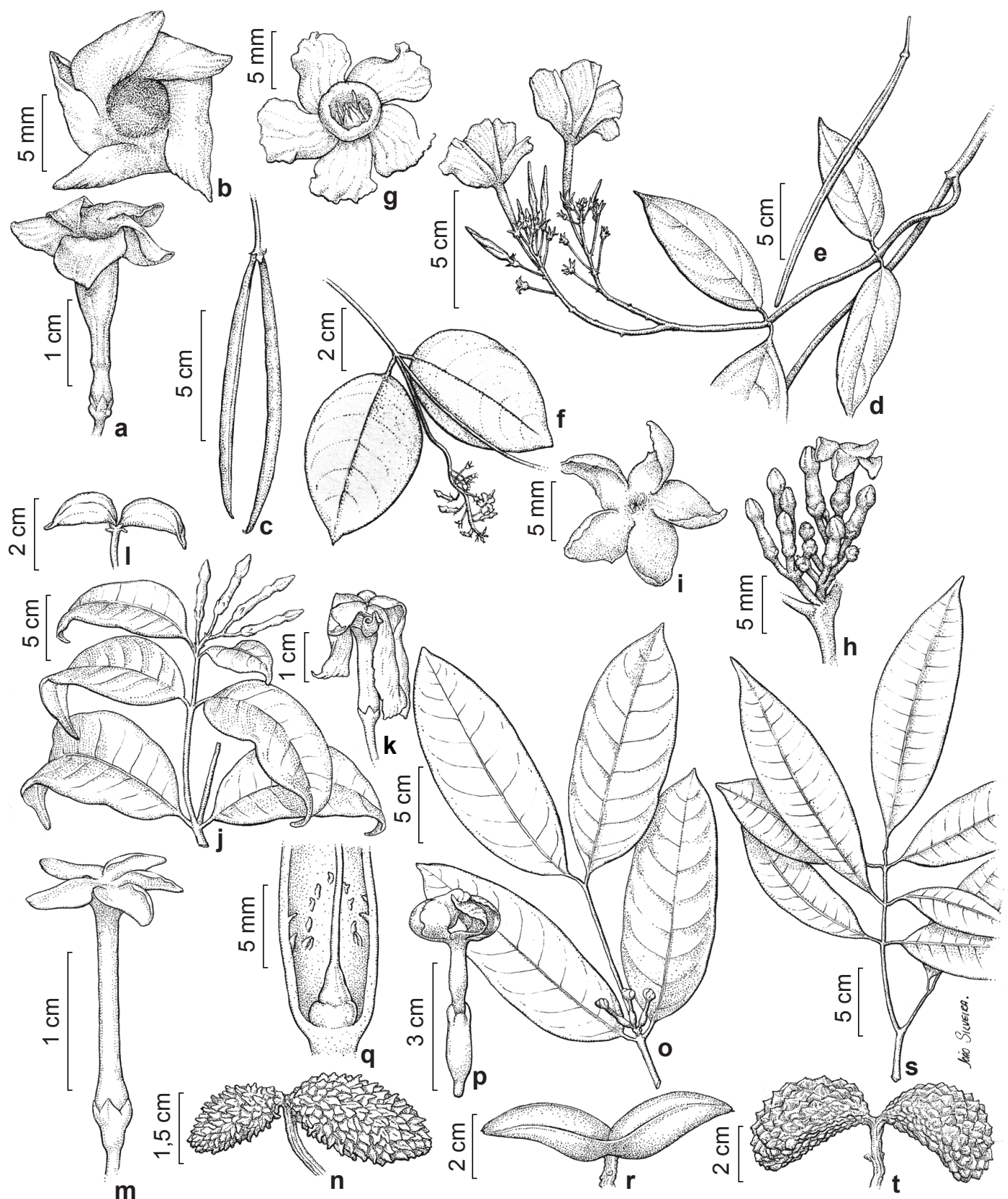

Figura 5 - a-c. Odontadenia nitida - a. flor em vista lateral; b. flor em vista frontal; c. fruto. d-e. Prestonia ornatad. ramo florífero; e. fruto. f-g. Prestonia quinquangularis - f. ramo florífero; g. flor em vista frontal. h-i. Secondatia densiflora $-\mathrm{h}$. inflorescência; i. flor em vista frontal. j-1. Tabernaemontana flavicans - j. inflorescência; $\mathrm{k}$. flor em vista lateral; 1. fruto. m-n. Tabernaeontana heterophylla - m. flor em vista lateral; $\mathrm{n}$. fruto. o-r. Tabernaemontana macrocalx - o. inflorescência; p. flor em vista lateral; q. coléteres calicinais; r. fruto. s-t. Tabernaemontana cf. linkii - s. ramo vegetativo; t. fruto (a-c. Arruda 313; Silva 1477; d-e. Secco 247; Fernandes 173; f-g. Secco 165; h-i. Hiura 73; j-1. Simões 1802; m-n. Costa 664, Holt 605; o-r. Arruda 1266, Almeida 2497; s-t. Giacomin 1155).

Figure 5 - a-c. Odontadenia nitida - a. flower in side view; b. flower in frontal view; c. fruit. d-e. Prestonia ornate - d. flowering branch; e. fruit. f-g. Prestonia quinquangularis - f. flowering branch; g. flower in frontal view. h-i. Secondatia densiflora - h. inflorescence; i. flower in frontal view. $\mathrm{j}-1$. Tabernaemontana flavicans - j. inflorescence; $\mathrm{k}$. flower in side view; 1 . fruit. m-n Tabernaeontana heterophylla - $\mathrm{m}$. flower in side view; n. fruit. o-r. Tabernaemontana macrocalyx - o. inflorescence; $\mathrm{p}$. flower in side view; q. calycine colleters; $r$. fruit. s-t. Tabernaemontana cf. linkii - s. vegetative branch; t. fruit (a-c. Arruda 313; Silva 1477; d-e. Secco 247; Fernandes 173; f-g. Secco 165; h-i. Hiura 73; j-1. Simões 1802; m-n. Costa 664, Holt 605; o-r. Arruda 1266, Almeida 2497; s-t. Giacomin 1155). 


\section{Chave de identificação das espécies Mandevilla das cangas da Serra dos Carajás}

1. Planta volúvel; coléteres ao longo da nervura primária da lâmina foliar; corola amarela, infundibuliforme 7.1. Mandevilla scabra

1'. Subarbusto ereto; coléteres somente na base da lâmina foliar; corola rósea a roxa, hipocrateriforme .. 7.2. Mandevilla tenuifolia

7.1. Mandevilla scabra (Hoffmanns. ex Roem. e Schult.) K.Schum., Nat. Pflanzenfam. 4: 171. 1895.

Figs. 2f-i; 3i-j

Planta volúvel. Ramos cilíndricos, sem lenticelas, pubescentes. Folhas com pecíolo 3-14 mm compr.; lâmina 37-10 × 8-45 mm, elíptica, ápice atenuado, base cordada, margem inteira, glabrescente na face adaxial e pubescente a tomentosa na face abaxial, com coléteres ao longo da nervura central na face adaxial, nervação broquidódroma. Inflorescências axilares, 4-23-floras, 1,7-6,9 cm compr.; pedúnculo 11-16 $\mathrm{mm}$ compr., piloso; brácteas estreito-triangulares. Flores com pedicelo 0,1-4 mm compr., pubescente; sépalas 1-2 × 1-1,5 mm, pilosas, lanceoladas, com coléteres opostos; corola infundibuliforme, amarela, pilosa, tubo inferior $26-31 \times 3-5 \mathrm{~mm}$, cilíndrico, tubo superior $2,2-3 \times 1,6-2,1 \mathrm{~cm}$, campanulado, lobos ca. 2,5 × 2,6 cm, patentes, obliquamente obovados; anteras ca. $1 \mathrm{~cm}$ comp., triangulares, lignificadas no dorso, ápice cuspidado, base sagitada, glabras; ovário ovoide, glabro, estilete ca. 3,1 cm compr., cabeça do estilete ca. 0,2 mm compr.; disco nectarífero 5-lobado. Folicários $3-25 \times 0,1-4 \mathrm{~cm}$, glabros; sementes 8-20 × 1-2 $\mathrm{mm}$, estreito-elípticas, glabras.

Material selecionado: Canaã doa Carajás, Serra Sul, S11D, 6²3'22”S 50²1'42”W 01.I.2015, fl., J.R. Trindade 349 (MG); Serra da Bocaina, 27.VI.2017. fr., G.E.A. Fernandes 174 (MG). Parauapebas, Serra Norte, N1, 602'35"S, 50¹6'57'W, 26.III.2015, fl., P.L. Viana et al. 5603 (MG); N2, 6.03'21”S, $50^{\circ} 15^{\prime} 15^{\prime}$ 'W, 28.IV.2015, f1., A. Gil et al.460 (MG); N3, 16.II.2017, f1., G.E.A. Fernandes 39 (MG); N4, $700 \mathrm{~m}$ elev., 14.III.1984, fl., A.S.L. da Silva et al. 1785 (MG); N5, 25.IV.2017, fr., G.E.A.Fernandes 128 (MG); N7, 6009'18”'S, 50¹0'20”'W, 690 m, 26.III.2016, fl., K. Rocha et al. 94 (MG). Ourilândia do Norte, Serra Arqueada, 6030'33"'S, 500.'23”'W, $633 \mathrm{~m}$ elev. 3.V.2016,fl., P.L. Viana 6196 (MG).

Mandevilla scabra difere-se das demais espécies da área de estudo pela presença de coléteres na nervura central da lâmina foliar e corola infundibuliforme amarela, levemente zigomorfa. Muitas vezes confundida com M. hirsuta por também apresentar flores infundibuliformes amarelas, porém $M$. scabra apresenta sépalas e brácteas menores e indumento piloso evidente nos ramos e folhas. Suas flores podem variar de amarelo claro a amarelo forte, mas sempre com a fauce vermelha.

A espécie apresenta ampla distribuição nos neotrópicos, do sudoeste do México ao norte da Argentina (BFG 2015). No Brasil ocorre nas regiões: Norte (AC, AM, AP, PA, RO, RR, TO), Nordeste (AL, BA, CE, MA, PB, PE, PI, RN, SE), Centro-Oeste (DF, GO, MS, MT), Sudeste (ES, MG, RJ, SP), Sul (PR, RS, SC) (BFG 2015). Ocorre nas cangas da Serra dos Carajás na Serra Norte: N1, N2, N3, N4, N5, N6, N7 sem registro para N8; Serra Sul: S11D a S11A; e Serra Arqueada. Encontrada nas área aberta e área de transição para mata, florescendo nos meses de outubro a maio e frutificando nos meses de janeiro a maio.

7.2. Mandevilla tenuifolia (J.C. Mikan) Woodson, Ann. Missouri Bot. Gard. 20(4): 679. 1933

Figs. 3k; 4a-c

Subarbusto ereto, com xilopódio, 5,5-42 $\mathrm{cm}$ alt., látex branco. Ramos cilíndricos sem lenticelas, escabrosos a glabros, com coléteres interpeciolares. Folhas com pecíolos $0,3-1 \mathrm{~mm}$; lâminas 5-5,2 × 1-2 mm, linear-lanceoladas, base atenuada, ápice agudo, margem inteira, glabras; nervação hipódroma. Inflorescências terminais, 5-12-floras, 0,8-30 cm; pedúnculo 2,8-13,5 cm, glabra, brácteas triangulares. Flores com pedicelo 2-10 mm compr., glabro; sépalas 2-4 × 0,5-1 $\mathrm{mm}$, glabras, estreito-triangulares, com coléteres contínuos; corola hipocrateriforme, branca, rosa a roxa, tubo inferior $1-1,4 \mathrm{~cm}$, cilíndrico, tubo superior 2-4 mm, cilíndrico, lobos ca. $8 \times 5 \mathrm{~mm}$, patentes, obovados; anteras ca. $2 \mathrm{~mm}$ compr., ápice, atenuado, base cordada, glabras; ovário piriforme, glabro, estilete ca. 1,3 cm comp.; cabeça do estilete fusiforme, ca. $0,8 \mathrm{~mm}$ compr.; disco nectarífero 2-lobado na base. Folicários 2-6 cm compr., glabros, lisos; sementes 4,5-6× ca. $1 \mathrm{~mm}$, fusiformes, pilosas.

Material selecionado: Canaã dos Carajás, S11A, 20.II.2017, fl. e fr., G.E.A. Fernandes 86 (MG). Marabá [Parauapebas], Serra Norte, N1, 6 ${ }^{\circ} 18^{\prime} 00^{\prime}$ 'S, 50¹6'59”W, 7.XII.2013, R.S. Santos 169 (MG). 
Parauapebas N2, 603'22"S, 50¹5'15'W, 23.II.2016, R.M. Harley 57360 (MG); N3, 14.III.1985, fl. e fr., $R$. Secco et al. 453 (MG); N4, 12.I.2010, L.C.B. Lobato 3798 (MG); N7, 609'31'S, 50¹0'10”'W, 24.II.2016, 709 m, R.M. Harley et al. 57385 (MG); N8, 6¹0'01's, 5009'29'W, 18.III.2015, L.C. Lobato 4343 (MG).

Mandevilla tenuifolia difere-se das demais espécies da área de estudo pelo seu hábito subarbustivo, formando moitas cujas flores variam de branco-arroxeadas quando novas a roxas em indivíduos com frutos. Espécie com ampla distribuição nos neotrópicos, em formações abertas (BFG 2015).

No Brasil, ocorre nas regiões: Norte (PA, RO, TO), Nordeste (AL, BA, CE, PB, PE, PI, RN, $\mathrm{SE}$ ), Centro-Oeste (DF, GO, MT), Sudeste (ES, MG, RJ, SP) (BFG 2015). Serra dos Carajás: Serra Norte: N1, N2, N3, N4, N7 e N8. Serra Sul: S11A. Encontrada em canga aberta, crescendo entre fendas, florescendo nos meses de dezembro a março e frutificando nos meses de fevereiro a março.

\section{Marsdenia R. Br.}

Plantas volúveis, com látex branco. Ramos cilíndricos, sem lenticelas, geralmente corticosos, glabros, com coléteres interpeciolares. Folhas opostas, com coléteres na base da face adaxial. Inflorescências cimeiras umbeliformes ou paniculiformes, subaxilares, alternas; sépalas com coléteres alternos; corola urceolada ou curto-campanulada, carnosa, lobos patentes ou reflexos; corona simples, segmentos livres entre si, carnosos, aderidos total ou parcialmente às anteras. Ginostégio subséssil; apêndice membranáceo apical das anteras oval-lanceolado, mais longo que a parte locular das anteras; retináculo bem menor que as polínias, caudículas ascendentes, polínias eretas, férteis em toda a extensão; apêndice estilar cônico. Folicários lisos; sementes comosas.

O gênero está distribuído do México ao sul do Brasil, norte da América do Sul e Nordeste do Brasil (Espirito-Santo 2017). No Brasil são registradas 34 espécies ocorrendo em todos os estados com exceção do Acre (BFG 2015). Na Serra dos Carajás está representada por duas espécies.

\section{Chave de identificação das espécies Marsdenia das cangas a Serra dos Carajás.}

1. Inflorescência cimeira umbeliforme; corola creme a branca, urceolada.............. 8.1. Marsdenia bergii

1'. Inflorescência paniculiforme; corola alva a roxa, curto-campanulada ............ 8.2. Marsdenia thomasii

8.1. Marsdenia bergii Morillo, Anales Jard. Bot. Madrid 51(1): 57-58. $1993 . \quad$ Figs. 31-p; 4d-e Folhas com pecíolos 3-22 mm compr.; lâminas $2-13 \times 0,8-5,5 \mathrm{~cm}$, oblongas a elípticas, ápice atenuado a cuspidado, base obtusa a atenuada, margem inteira, cerosas. Inflorescências cimeira umbeliformes, 3-20-floras; pedúnculo 2-13 mm, glabro, brácteas ovais. Flores com pedicelo $0,3-1,3 \mathrm{~mm}$, piloso; sépalas ca. $2 \times 1,5$ $\mathrm{mm}$, pubescentes, elípticas; corola urceolada, creme a branca, glabra, tubo $3 \mathrm{~mm}$, lobos ca. 2 $\mathrm{mm}$, patentes, pilosos, oblongos; corona ca. 3 $\times 1,5 \mathrm{~mm}$, parte inferior auriculada, adnatas ao dorso da antera, parte superior triangular, livre, ultrapassando a cabeça do estilete; ginostégio ca. $4 \mathrm{~mm}$; anteras ca. $1,5 \mathrm{~mm}$, retangulares, apêndice da antera ca. 0,17 mm compr.; retináculo ca. $0,25 \times 0,9 \mathrm{~mm}$, ovoide, da mesma altura que os polínias, caudículas ca. 0,9 $\mathrm{mm}$ compr. inseridas na base das polínias, membrana hialina, polínias ca. 0,29 ×0,18 mm, ovoides; apêndice estilar ovoide; ovário ovoide, glabro. Folicários $6,5-11,5 \mathrm{~cm}$, glabros; sementes ca. $7 \times 5 \mathrm{~mm}$, obovoides.
Material selecionado: Canaã dos Carajás, Serra Sul, S11A, 6020'57”S, 50²6'55”'W, 719 m, 17.IX.2016, fl., L.V. Vasconcelos et al. 971 (MG); Corpo B, 11.X.2008, fl., L.V. Costa et al. 577 (BHCB); Pedra da Harpia, 19.II.2017, fr., G.E.A. Fernandes et al. 77 (MG). Parauapebas, Serra Norte, N5, 18.II.2017, fl., G.E.A. Fernandes et al. 67 (MG); N7, 17.II.2017, fr., G.E.A. Fernandes et al. 50 (MG).

Marsdenia bergii, quando vegetativa, pode ser confundida com M. amylacea (Barb. Rodr.) Malme, que também ocorre no estado do Pará mas não tem registro para Carajás e possui flores de corola urceolada dispostas em inflorescências escorpioides. Das demais espécies da área de estudo, difere-se pela inflorescência umbeliforme com flores urceoladas e corona com a parte superior livre ultrapassando a cabeça do estilete.

Endêmica do Brasil, ocorre apenas na região: Norte (PA) (BFG 2015). Serra dos Carajás: Serra Sul: S11A, S11B, Pedra da Harpia e Serra Norte: N5 e N7. Encontrada e área de transição da mata e canga aberta, florescendo de setembro a fevereiro e com frutos no mês de fevereiro. 
8.2. Marsdenia thomasii Morillo, Ernstia 8(1): 6-8. 1998.

Fig. 3q-t

Folhas com pecíolos 10-15 mm compr.; lâminas 13-6×3-6 cm, elípticas, ápice agudo, base obtusa, glabras. Inflorescências paniculiformes, 17-37-floras; pedúnculo 10-15 mm compr., glabro, brácteas ovais, ciliadas. Flores com pedicelo 3-5 $\mathrm{mm}$ compr., glabrescente; sépalas ca. $1 \times 2 \mathrm{~mm}$, ciliadas, ovais; corola curto-campanulada, alva a roxa, puberulenta, tubo ca. $1 \mathrm{~mm}$, lobos ca. 4 $\mathrm{mm}$, reflexos, oblongos, glabros; corona ca. 1,7 $\mathrm{mm}$, lobos oblongos a obovados, adnatos à base das anteras, ápice retuso, livres, ultrapassando a cabeça do estilete; ginostégio ca. $2 \mathrm{~mm}$ compr.; anteras ca. 1,3 mm compr., retangulares, apêndice da antera ca. $0,3 \mathrm{~mm}$ compr.; retináculo $0,14-0,17$ $\times$ ca. $0,03 \mathrm{~mm}$, linear, ápice arredondado, ereto, caudículos $0,1-0,14 \mathrm{~mm}$ compr., polínias ca. $0,5 \times$ $0,14 \mathrm{~mm}$, obovoides, subfalcadas; ovário ovoide, glabro. Frutos e sementes não vistos.

Material selecionado: Parauapebas, Serra dos Carajás, estéril sul, 24.X.1988, fl., J.P. Silva (142-A) (HCJS).

Marsdenia thomasii difere-se das demais espécies da área de estudo pela sua inflorescência paniculiforme pendente, corola curto-campanulada e corona oblonga e ápice emarginado (Fig. 3s). Endêmica do Brasil, ocorre nas regiões: Norte (PA), Centro-Oeste (MT) (BFG 2015). Serra dos Carajás: Estéril Sul, florescendo no mês de outubro.

\section{Matelea Aubl.}

Plantas volúveis, com látex branco. Ramos cilíndricos, sem lenticelas, glabros, com coléteres intrapeciolares. Folhas opostas, com coléteres na base da face adaxial. Inflorescências extraxilares; sépalas com coléteres alternos; corola esverdeada, rotacea lobos patentes, corona interestaminal, triangular, adnata a corola e ao ginostégio. Ginostégio séssil; retináculo menor que as polínias, caudículas ovoides, polínias férteis em toda a extensão; apêndice estilar plano. Folicários lisos; sementes comosas.

9.1. Matelea microphylla Morillo. Ernstia 50: 26, 28. 1988.

Fig. $3 \mathrm{u}-\mathrm{x}$

Planta volúvel, látex branco. Ramos cilíndricos, sem lenticelas, com coléteres intrapeciolares, pilosos. Folhas com pecíolo 1-3 mm compr.; lâminas $12-30 \times 2-8 \mathrm{~mm}$, estreito elípticas, ápice cuspidado, base subcordada, glabrescentes na nervura central, com 2-3 coléteres na base. Inflorescências extra-axilares, 4-6 mm compr., 1-4 floras; pedúnculo 1-2 mm, glabro.
Flores com pedicelo ca. $3 \mathrm{~mm}$ compr., escabro; sépalas ca. $2 \times 1 \mathrm{~mm}$, pilosas na face adaxial, elípticas, com coléteres alternos; corola rotácea, esverdeada, lobos ca. $3,4 \times 2,6 \mathrm{~mm}$, glabros. Ginostégio séssil, ca. 2,6 mm; anteras ca. 1,4 mm compr., retangulares, apêndice da antera ca. 0,2 $\mathrm{mm}$; corona interstaminal ca. $1 \times 1,3 \mathrm{~mm}$, adnata à corola e ao ginostégio, base fimbriada; retináculo ca. $0,3 \times 0,2 \mathrm{~mm}$; caudículas ca. $0,2 \times 0,3 \mathrm{~mm}$ horizontais, ovoides, polínias ca. $0,5 \times 0,3 \mathrm{~mm}$; apêndice estilar plano. Ovário ovoide, glabro. Folicário aristado longituditalmente, ca. 5,5 × 0,8 $\mathrm{cm}$; sementes não vistas.

Material selecionado: Parauapebas, Serra Norte, $5^{\circ} 55^{\prime} \mathrm{S}$ 50²6'W, 5.XII.1981, fl., D.C. Daly et al. 1713 (MG; NYBG). N2, 31.V.2017, fl., F.M.G. Santos et. al. 390 (MG). N3, 24.VI.2017, fl., F.M.G. Santos et al. 391 (MG). Serra do Cristalino, 6 $27^{\prime} 31^{\prime \prime} \mathrm{S}, 49^{\circ} 40^{\prime} 49^{\prime \prime} \mathrm{W}$, 24.V.2016, fl. e fr., B.F. Falcão. et al. 559 (MG). Serra Arqueada, 3.V.2017, fl., F.M.G. Santos et. al. 387 (MG). 2.V.2017, fl., F.M.G. Santos et. al. 388 (MG). 2.V.2017, fl., F.M.G. Santos et. al. 389 (MG).

Matelea microphylla difere-se das demais espécies da área de estudo por apresentar folhas pequenas com lâmina estreito-oblonga, corola rotácea com lobos medindo ca. 3,4 × 2,6 $\mathrm{mm}$, corona interestaminal e folicário aristado longitudinalmente.

Espécie endêmica da Serra dos Carajás, onde foi registrada na Serra Norte: N1, N2, N3, Serra Arqueada e Serra do Cristalino, com flores nos mêses de dezembro e junho e com frutos no mês de maio.

\section{Odontadenia Benth.}

Planta volúvel, lenhosa, látex branco. Ramos cilíndricos com coléteres interpeciolares diminutos ou conspícuos, de aparência foliar e similares a pequenas estípulas. Folhas opostas, raramente verticiladas, glandulares. Inflorescências cimosas escorpioides, axilares; brácteas escariosas e inconspícuas; sépalas iguais ou desiguais, com coléteres alternos; corola infundibuliforme; ginostégio presente; estames inclusos, adnatos a cabeça do estilete; cabeça do estilete fusiforme; ovário apocárpico. Folicários 2, raro 1 por aborto; sementes comosas.

Gênero de lianas com espécies distribuídas da Guatemala ao Brasil e Índias Ocidentais (República Dominicana e Haiti). Algumas espécies são de ampla distribuição, mas a maioria está restrita a América Central e norte da América do Sul, em floresta de terras baixas (Morales 1999). No Brasil são registradas 16 espécies, ocorrendo em 
quase todos os estados e predominantemente na Amazônia (BFG 2015). Na Serra dos Carajás está representada por uma espécie.

10.1. Odontadenia nitida (Vahl) Müll. Arg., Fl. bras. 6(1): 118. $1860 . \quad$ Figs. 4f-g; 5a-c

Folhas com pecíolo 3-6 $\mathrm{mm}$; lâminas 2,4-11 × 0,8-6,5 cm, oblongo-ovadas, ápice obtuso, base cordada, margem inteira, glabras. Inflorescências 6-14-floras, 3-9 cm compr.; pedúnculo 1,7-5,5 cm compr., glabra; brácteas deltoides. Flores com pedicelo 1,5-5,5 cm, glabro; sepálas 2-3 × 2-3 mm, glabras, ovais; corola amarela a amarelo-alaranjada, glabra, tubo inferior 6-8 $\times 2-3 \mathrm{~mm}$, cilíndrico, tubo superior 13-28 $\times 5-9 \mathrm{~mm}$, campanulado, lobos ca. $10 \times 8$ $\mathrm{mm}$, patentes, obliquamente obovados; anteras ca. $8 \mathrm{~mm}$, lignificadas no dorso, ápice agudo, base sagitada, glabras; ovário ovoide, glabro, estilete ca. $8 \mathrm{~mm}$; cabeça do estilete $2-3 \mathrm{~mm}$; disco nectarífero 5-lobado. Folicários ca. 2,1 $\times$ $6 \mathrm{~cm}$ glabros, lisos; sementes ca. 1,3 cm compr., comosas.

Material selecionado: Canaã dos Carajás, Serra Sul, S11D, 22.VI.2013, fl., R.S. Santos 30 (MG). Marabá [Parauapebas], Serra Norte, N1, 6¹9'39'S, $50^{\circ} 10^{\prime} 28^{\prime \prime} \mathrm{W}, 13 . \mathrm{X} .2008$, fl., L.V. Costa et al. 636 (BHCB); N4, 700 m, 15.III.1984, fl., M.R. Santos et al. 1839 (MG). Parauapebas, N5, 14.V.1982, fl., $L$. Marinho et al. 167 (MG).

Odontadenia nitida, quando vegetativa, é muito semelhante a $O$. geminata, principalmente pelas folhas glabras, sépalas iguais entre si e ocorrência no estado do Pará (Morales et al. 2013), diferindo-se pela inflorescência escorpioide ( $v s$. dicásio), corola infundibuliforme ( $v s$. hipocrateriforme) e tubo sem nódulos na parte exterior do tubo ( $v s$ nódulos visíveis na corola) (Fig. 5g) (Viana et al. 2017).

Espécie com ampla ocorrência, do Caribe ao Centro-Oeste Brasileiro, Bolívia e Peru (BFG 2015). No Brasil ocorre nas regiões: Norte (AC, AM, AP, PA, RO, RR), Centro-Oeste (MT) (BFG 2015). Serra dos Carajás: Serra Norte: N1, N4, N5 e Serra Sul: S11D. Geralmente encontrada e canga aberta, apoiando-se em árvores e arbustos, florescendo de março a outubro e com frutos no mês de junho.

\section{Prestonia $\mathrm{R} . \mathrm{Br}$.}

Plantas volúveis ou subarbustos. Ramos com lenticelas, coléteres nodais presentes. Folhas opostas, coléteres ausentes, domácias ausentes, nervação broquidódroma. Inflorescências racemosas, axilares; sépalas iguais, com coléteres opostos; corola hipocrateriforme ou infundibuliforme, fauce com anel caloso conspícuo ou inconspícuo; ginostégio presente; estames inclusos, adnatos a cabeça do estilete; apêndices supraestaminais presentes ou ausentes; cabeça do estilete fusiforme com espessamento basal. Folicários ou cápsulas septícidas; sementes comosas.

Gênero neotropical, com cerca de 60 espécies, ocorre desde as Antilhas até o sul do Brasil e norte da Argentina, em matas, cerrados e mais raramente em restingas (Kinoshita et al. 2005). No Brasil são registradas 23 espécies, em todos os biomas (BFG 2015). Na Serra dos Carajás está representado por duas espécies.

\section{Chave de identificação das espécies de Prestonia ocorrentes nas cangas a Serra dos Carajás}

1. Lâmina foliar elíptica; corola infundibuliforme, tubo superior $10 \mathrm{~mm}$ compr., sem anel caloso na fauce 11.1. Prestonia ornata

1'. Lâmina foliar oblonga a ovada; corola hipocrateriforme, tubo superior 3-5 mm compr., com anel caloso conspícuo na fauce 11.2. Prestonia quinquangularis

11.1. Prestonia ornata (Hoehne) J.F. Morales, M.E. Endress \& Liede, Taxon 63: 639. 2017.

Fig. 5d-e

Planta volúvel, látex incolor. Ramos cilíndricos com lenticelas, puberulentos a glabros, com coletéres interpeciolares. Folhas com pecíolos 3-16 mm compr.; lâminas 4-16 × 1,5-7,5 cm, elípticas, ápice atenuado a agudo, base cuneada, margem inteira, glabras. Inflorescências racemosas, 10-12-floras, 2-18,5 cm; pedúnculo $15-65 \mathrm{~mm}$ compr., puberulento; brácteas deltoides a lineares. Flores com pedicelo 1-2,3 cm compr., pubescente; sépalas ca. $7 \times 1 \mathrm{~mm}$, ovais, pubescentes, com coléteres contínuos; corola infundibuliforme, amarela, tubo inferior $7-12 \times 2-3 \mathrm{~mm}$, tubo superior ca. $10 \times 4-7 \mathrm{~mm}$, lobos $2-3 \times$ ca. $2 \mathrm{~mm}$, patentes, obliquamente obovados, sem anel caloso na base; anteras ca. $5 \mathrm{~mm}$, sagitadas, glabras; ovário 
ovoide, pubescente, estilete ca. $8 \mathrm{~mm}$, cabeça do estilete fusiforme, ca. $1 \mathrm{~mm}$ compr.; disco nectarífero 5-lobado. Cápsula 9,3-26 × 0,2-0,5 $\mathrm{cm}$, glabra; sementes ca. $12 \times 2 \mathrm{~mm}$, fusiformes. Material selecionado: Canaã dos Carajás, Serra da Bocaina, 6029'41"S, 4991' '"'W, 684 m, 27.VI.2017, fr., G.E.A. Fernandes et al. 173 (MG). Parauapebas, Serra Norte, N1, 17.V.1982, fl., R. Secco et al. 247 (MG).

Prestonia ornata difere-se das demais espécies na área de estudos principalmente pelo látex incolor, corola infundibuliforme e frutos capsulares, moniliformes. Esta espécie, tradicionalmente reconhecida em Temnadenia e transferida recentemente para o gênero Prestonia por Morales et al. (2017), ocorre do noroeste do Brasil ao sudeste do Peru e nordeste da Bolívia (Morales 2005a). No Brasil ocorre nas regiões: Norte (AC, AM, PA, RO) e Centro-Oeste (MT) (BFG 2015). Serra dos Carajás: Serra Norte: N1, e Serra da Bocaina. Encontrada em área de canga aberta, florescendo no mês de maio e com frutos no mês de junho.

11.2. Prestonia quinquangularis (Jacq.) Spreng., Syst. Veg. 1: 637. 1825[1824]. Fig. 5f-g

Planta volúvel, látex incolor. Ramos cilíndricos a compressos, lenticelados, escabros a glabrescentes, com coléteres intrapeciolares. Folha com pecíolo 1-8 mm; lâminas 7,5-11 $\times 3,3-6,5 \mathrm{~cm}$, oblongas ou ovadas, ápice atenuado, base arredondada, margem inteira, glabras. Inflorescências 7-20-floras, 3-8,5 cm compr.; pedúnculo 1,4-5,3 cm, escabro; brácteas triangulares a deltoides. Flores com pedicelo 1-8 mm, pubescente; sepálas 3-4 × ca. $1 \mathrm{~mm}$, ovais, pubescentes, com coléteres opostos; corola amarela, pubescente, tubo inferior 10-14 $\mathrm{mm}$, tubo superior 3-5 mm, lobos $8-10 \times 7 \mathrm{~mm}$, amarelo-arroxeados, patentes, obliquamente obovados, com anel caloso branco espesso na base; anteras ca. 4,5 mm, lignificadas, ápice agudo, base sagitada, glabras; ovário ovoide a fusiforme, pubescente, cabeça do estilete ca. 1 $\mathrm{mm}$ compr.; disco nectarífero 5-lobado. Cápsula $8,3-29,2 \times 2-5 \mathrm{~cm}$, escabra; sementes ca. $12 \times 1$ $\mathrm{mm}$, prismáticas.

Material selecionado: Marabá [Parauapebas], Serra Norte, N5, 14.V.1982, fl., R. Secco 165 (MG).

Material adicional: BRASIL. PARÁ. Santarém, Alter do Chão, coleta entre 1998 e 2005, fl e fr., O.H. Knowles 1458 (MG).

Prestonia quinquangularis difere-se das demais espécies na área de estudos pela sua flor com anel caloso espesso na fauce da corola. A espécie possui ampla distribuição do Sul da Nicarágua e Índias Ocidentais alcançando a Bolívia, Paraguai e Argentina (Morales 2005b). No Brasil, ocorre nas regiões: Norte (AC, AM, PA, RO), Nordeste (BA, CE, PI), Centro-Oeste (DF, GO, MS, MT), Sudeste (MG, RJ, SP), Sul (PR) (BFG 2015). Serra dos Carajás: Serra Norte: N5, florescendo no mês de maio.

\section{Secondatia A. DC.}

Plantas volúveis, lenhosas, látex branco. Ramos com lenticelas, coléteres nodais interpeciolares ou ao longo de toda a região nodal. Folhas opostas, nervação broquidódroma. Inflorescências terminais, cimosas; sépalas iguais ou subiguais, com coléteres alternos; corola hipocrateriforme, pré-floração dextrorsa; ginostégio presente; estames inclusos, adnatos a cabeça do estilete; ovário apocárpico; cabeça do estilete fusiforme. Folicários 2; sementes comosas.

A distribuição do gênero é neotropical com seis espécies. Destas, cinco são exclusivamente sul-americanas e apenas uma, Secondatia macnabii (Urb.) Woodson, ocorre na América Central (BFG 2015). No Brasil são registradas três espécies com ocorrência em quase todos os estados (BFG 2015). Na Serra dos Carajás está representado por uma espécie.

12.1. Secondatia densiflora A. DC. Prodr. 8: 445. 1844.

Figs. $4 \mathrm{~h} ; 5 \mathrm{~h}-\mathrm{i}$

Planta com ramos cilíndricos. Folhas com pecíolo 2-10 mm compr.; lâminas 7,5-12,2 × $3,7-5,7 \mathrm{~cm}$, elípticas, ovadas ou oblongas, ápice acuminado, base obtusa, margem inteira, glabras. Inflorescências congestas, 27-17-floras, 6-20 $\mathrm{mm}$ compr.; pedúnculo $0,5-1,5 \mathrm{~mm}$ compr., pubescente; brácteas obovadas a deltoides. Flores com pedicelo $0,3-0,7 \mathrm{~mm}$, pubescente; sépalas ca. $1 \mathrm{~mm}$, pilosas, ovais, com coléteres alternos; corola hipocrateriforme, branca, tubo ca. $2,5 \times 7 \mathrm{~mm}$, cilíndrico, glabro, lobos ca. $4,5 \times 5 \mathrm{~mm}$, patentes, obliquamente obovados, pilosos; anteras ca. $3 \mathrm{~mm}$ compr., lignificadas, triangulares, pilosas no ápice; ovário ovoide, glabro; estilete ca. $1 \mathrm{~mm}$; cabeça do estilete ca. $1 \mathrm{~mm}$.; disco nectarífero lobado. Folicários lenhosos, falciformes, 3-9,2 × 1,2-2 cm, glabro; sementes ca. $20 \times 5 \mathrm{~mm}$, elipsoides.

Material selecionado: Canã̃ dos Carajás, Serra Sul, Corpos A, B e C, 6 20'43"S, 50²4'29'W, 8.XII.2007, $617 \mathrm{~m}$, fl., N.F.O. Mota et al. 1130 (BHCB); S11D, 6²3'62”S, 50²2'26”'W, 677 m, 1.XII.2015, fl., T.S. Praia 
et al. 23 (MG). Parauapebas, Serra Norte, N3, 18.V.2016, fr., A.L. Hiura et al. 73 (MG); N4, 6¹0'01'S, 50¹1'31'"W, 24.VIII.2015, fl., L.C.B Lobato 4441 (MG); N5, 602'28”'S, 5005'16”', 02.IX.2015, fl., A. Gil et al. 511 (MG); N6, $6^{\circ} 10^{\prime} 48^{\prime}$ 'S, 5008'48'W, 716 m, fr., 26.III.2016, J. Meirelles et al. 977 (MG).

Secondatia densiflora difere-se das demais espécies da área de estudo por apresentar folhas glabras, inflorescências terminais congestas e folicários falciformes. Liana lenhosa, pode ser encontrada em área de canga arbustiva apoiada em árvores de pequeno porte ou arbustos, perto de córregos e canga aberta apoiada em arbustos.

Espécie com ampla distribuição no centro e sul da América do Sul, alcançando o Paraguai e Norte da Argentina (BFG 2015). No Brasil, ocorre nas regiões: Norte (AC, AM, PA, RO, RR, TO), Nordeste (BA, CE), Centro-Oeste (DF, GO, MS, MT), Sudeste (MG, RJ, SP) (BFG 2015). Serra dos Carajás: Serra Norte: N3, N4, N5 e N6 e Serra Sul: S11A, S11B, S11C e $\mathrm{S} 11 \mathrm{D}$, florescendo nos meses de agosto a janeiro, frutificando nos meses de março a maio.

\section{Tabernaemontana L.}

Arbustos ou árvores de pequeno porte, látex branco. Folhas opostas, glabras a pubescentes, pecioladas a subsésseis. Inflorescências cimosas ou paniculadas, axilares ou subterminais, pauci a multifloras, laxas ou congestas; sépalas iguais ou subiguais, geralmente com coléteres opostos na base; corola hipocrateriforme, pré-floração sinistrorsa; ginostégio ausente; estames completamente inclusos, anteras não adnatas à cabeça do estilete; cabeça do estilete fusiforme a pentagonal; ovário apocárpico a hemissincárpico, nectário ausente ou presente. Fruto folicário, raro bacoide, liso ou muricado, composto por dois mericarpos separados ou unidos na base; sementes ariladas, arilo branco, amarelo ou vermelho.

Gênero pantropical com cerca de 100 espécies, das quais 45 são neotropicais (Leeuwenberg 1994). No Brasil são registradas 30 espécies com distribuição para todos os estados com exceção do Piauí, Rio Grande Norte e Paraíba (BFG 2015). Na Serra dos Carajás, o gênero está representado por quatro espécies.

\section{Chave de identificação das espécies de Tabernaemontana ocorrentes nas cangas da Serra dos Carajás}

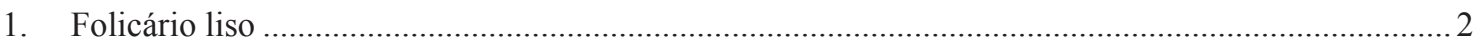

2. Corola creme; sépalas lanceoladas, escariosas; lobos da corola reflexos

13.1. Tabernaemontana flavicans

2'. Corola creme com manchas arroxeadas na metade inferior; sépalas oblongas, carnosas; lobos da corola inflexos..... 13.3. Tabernaemontana macrocalyx

1'. Folicário muricado 13.2. Tabernaemontana heterophylla

3. Folhas com heterofilia marcante 13.4. Tabernaemontana cf. linkii

13.1. Tabernaemontana flavicans Will. ex Roem. \& Schult., Syst. Veg. 4: 797. 1819.

Figs. $4 \mathrm{i}-\mathrm{j} ; 5 \mathrm{j}-1$

Arbusto $2 \mathrm{~m}$. Ramos cilíndricos, sem lenticelas, glabros, com coléteres intrapeciolares. Folha com pecíolo $2-7 \mathrm{~mm}$, lâminas $2-9,8 \times$ $0,7-3,8 \mathrm{~cm}$, obovadas a elípticas, ápice agudo a atenuado, base atenuada, margem inteira, glabras. Inflorescências axilares, cimosas, 6-10-floras, congestas, 3-6,5 cm compr.; pedúnculo 5-10 $\mathrm{mm}$, glabro; brácteas deltoides com coléteres. Flores com pedicelo 2-7 mm compr., glabro; sepálas 4-5 × 2-3 mm, lanceoladas, glabras, com coléteres opostos; corola hipocrateriforme, creme com a fauce amarela, glabra, tubo inferior 5-20 × 2-3 mm, tubo superior 3-10 × 2-3 mm, lobos ca. $3 \times 2 \mathrm{~cm}$, reflexos, glabros, obovados; anteras ca. $5 \mathrm{~mm}$ compr., ápice agudo, base sagitada, glabras; ovário piriforme, glabro, estilete ca. $2,2 \mathrm{~cm}$, cabeça de estilete fusiforme, ca. $1 \mathrm{~mm}$ compr.; disco nectarífero ausente. Folicários lisos, 16-18 × 6-8 mm, glabros; sementes com arilo vermelho.

Material selecionado: Canaã dos Carajás, Serra Sul, S11B, 621'06”'S, 50²3'43”'W, 23.III.2016, fl., R.M. Harley et al. 57457 (MG); Serra Sul, S11D, 6022'23"S, $50^{\circ} 21^{\prime} 09^{\prime \prime} \mathrm{W}, 729$ m, 3.XII.2015, fl. e fr. A.O. Simões 1802 (MG); S11D, 623'46”'S, 50²2'27”'W, $751 \mathrm{~m}$, 22.III.2016, fl., R.M. Harley 57427 (MG); Serra do Rabo [Bocaina], 618'36”'S, 49 53'22”'W, $692 \mathrm{~m}$, 13.X.2007, fl., N.F.O. Mota et al. 1168 (MG, BHCB).

Tabernaemontana flavicans difere-se das demais espécies do gênero na área de estudo pelas flores hipocrateriformes grandes de cor creme e fauce amarela e pelos lobos reflexos, diferindo de T. heterophylla também pelas flores menores hipocrateriformes e de $T$. macrocalyx 
pelos lobos inflexos. Ocorre na Venezuela, Peru e Brasil (Leeuwenberg 1994). Já no Brasil, ocorre nas regiões: Norte (AM, PA, RO), Nordeste (AL, BA, MA, PE), Centro-Oeste (MT) e Sudeste (ES, MG, RJ) (BFG 2015). Serra dos Carajás: Serra Sul: S11B, S11D e Serra da Bocaina. Encontrada em área de transição da mata baixa para a canga aberta, florescendo nos meses de outubro a março com frutos em dezembro.

13.2. Tabernaemontana heterophylla Vahl, Eclog. Amer. 2: 22. 1798.

Fig. 5m-n

Arbusto a arvoreta 1,5-5 m alt. Ramos cilíndricos, sem lenticelas, glabros, com coléteres intrapeciolares. Folhas com pecíolo 3-10 mm compr.; lâminas 5,8-19 × (0,6-)5-7 cm, elípticas, ápice atenuado a agudo, base atenuada, margem inteira, glabras, com heterofilia evidente. Inflorescências axilares, cimosas, 1-13-floras, 2-4 cm compr.; pedúnculo 5-20 $\mathrm{mm}$ compr., glabro a pubescente; brácteas deltoides, com coléteres. Flores com pedicelo 1-9 mm, glabro; sépalas ca. $1 \times 1 \mathrm{~mm}$, ovadas, glabras, com coléteres contínuos; corola hipocrateriforme, branca, glabra, tubo inferior ca. $1 \times 1-2 \mathrm{~mm}$, tubo superior 5-11 $\times$ ca. $1 \mathrm{~mm}$, lobos ca. 3 $\times 2-3 \mathrm{~mm}$, inflexos, pilosos, obliquamente obovados; anteras ca. $4 \mathrm{~mm}$, sagitadas, ápice agudo, base sagitada, glabras; ovário ovoide, glabro, estilete inconspícuo, cabeça do estilete fusiforme ca. 1,5 mm; disco nectarífero circular. Folicários rugosos a muricados, 15-17 × 10-20 $\mathrm{mm}$, glabros, avermelhados quando maduros, alongados, não depressos ventralmente; sementes não vistas.

Material selecionado: Canaã do Carajás, Serra Sul, Corpo D, 6²3'29'S, 50¹9'4”'W, 594 m, 31.VIII.2010, fl. e fr., T.E. Almeida et al. 2508 (BHCB); Serra do Tarzan, 15.X.2008, fl., L.V. Costa et al. 664 (BHCB). Parauapebas, Serra Norte, 609'92"S, 5094'92"W, 15.XII.2008, fr., C.V. Vidal 644 (BHCB).

Tabernaemontama heterophylla difere-se das demais espécies da área de estudo pelas suas folhas opostas com heterofilia marcante e flores com tubo da corola estreito.

A espécie possui ampla distribuição na América Central e norte da América do Sul, em sub-bosque. No Brasil, ocorre nas regiões: Norte (AC, AM, PA, RO e RR) (BFG 2015). Serra dos Carajás: Serra Norte, Parauapebas e Serra Sul, Corpo D e Serra do Tarzan. Encontrada geralmente e área de transição entre mata e canga, florescendo e frutificando nos meses de agosto a dezembro
13.3. Tabernaemontana macrocalyx Mull. Arg., Linnaea 30: 403. $1860 . \quad$ Figs. 31-m; 5p-s

Arbusto a arvoreta, 1-4 m alt. Ramos cilíndricos, sulcados, sem lenticelas, pubescentes a escabrosos, com coléteres intrapeciolares. Folhas com pecíolo 3-10 mm; lâminas 11,5-26,5 $\times 6-9 \mathrm{~cm}$, elípticas, ápice atenuado, base atenuada, glabras, margem inteira, glabras. Inflorescências axilares, cimosas, congestas, 1-9-floras, 2-6 cm compr.; pedúnculo 3-5 mm compr., pubescente; brácteas ovais. Flores com pedicelo inconspícuo, glabro; sépalas 13-18 mm, tubulosas, crassas, glabras, com diversos coléteres contínuos; corola hipocrateriforme, branca a rosada, com manchas vináceas conspícuas na metade inferior, glabra, tubo inferior 10-25 $\times 2-4 \mathrm{~mm}$, tubo superior $7-13 \times 2-5 \mathrm{~mm}$, lobos 10-13 $\times 6-8 \mathrm{~mm}$, inflexos, obliquamente obovados; anteras ca. $5 \mathrm{~mm}$ compr., ápice agudo, base sagitada, glabras; ovário ovoide, glabro, estilete ca. $15 \mathrm{~mm}$ compr., disco nectarífero circular; cabeça do estilete em forma de carretel, ca. $1 \mathrm{~mm}$. Folicário liso, lenhoso $43-50 \times 10-15 \mathrm{~mm}$, glabro; sementes $7-9 \times 3-5$ $\mathrm{mm}$, arilo branco.

Material selecionado: Canaã dos Carajás, Serra Sul, Corpo A, 6¹9'09"S, 50²6'11”W, $658 \mathrm{~m}$, 30.VIII.2010, fl., T.E. Almeida et al. 2497 (BHCB); Corpo B, 6 21'21's, 50²3'23”'W, 820 m, 4.VII.2010, f1., M.O. Pivari et al. 1641 (BHCB); S11D, 6²2'23"S, $50^{\circ} 21^{\prime}$ '09”'W, 729 m, 3.XII.2015, fl., A.O. Simões 1807 (MG). Parauapebas, Serra Norte, N1, 02.VI.1983, fr., M.F.F. Silva et al. 1328 (MG); N3, 6²'34"'S, $50^{\circ} 13^{\prime} 11$ 'W, $621 \mathrm{~m}, 22 . \mathrm{VIII} .2012$, fr., A.J. Arruda et al. 1266 (BHCB); N5, 18.II.2017, fl., G.E.A. Fernandes et al. 60 (MG).

Tabernaemontana macrocalyx difere-se das demais espécies na área de estudo pela sua flor carnosa com as sépalas bastante desenvolvidas e portando fileiras de coléteres na face abaxial e pelos lobos da corola inflexos (Fig. 5q).

Espécie com distribuição no Norte da América do Sul (Leeuwenberg 1994). No Brasil ocorre nas regiões: Norte (AC, AM, AP e RO) (BFG 2015). Serra dos Carajás: Serra Norte, N1, N3 e N5 e Serra Sul, S11A, S11B e S11D. Pode ser encontrada no sub-bosque em áreas de transição entre floresta e canga, onde pode ser bastante comum, florescendo nos meses de dezembro a agosto e frutificando nos meses de abril a agosto.

13.4. Tabernaemontana cf. linkii A. DC., Prod. Syst. Nat. Reg. Veg. 8: 364. $1844 . \quad$ Fig. 5s-t Arbusto, 2-3 m alt. Ramos cilíndricos, cerosos, sem lenticelas, com coléteres 
intrapeciolares. Folhas com pecíolo $5-14 \mathrm{~mm}$ compr.; lâminas 6-19 × 2-6,5 cm, elípticas a estreitoelípticas, ápice atenuado a agudo, base obtusa a atenuada, margem inteira, pilosas a glabrescentes. Inflorescências axilares, cimosas. Flores não vistas. Folicários 2, muricados, elipsoides, depressos ventralmente, 3-43 × 2-25 mm, glabros; sementes $3-5 \times 2-3 \mathrm{~mm}$.

Material selecionado: Canaã dos Carajás, Serra Sul, Corpo B, 6020'25"S, 50²4'30,57'W, 565 m, 19.V.2010, fr., L.L. Giacomin et al. 1155 (BHCB); ADA esteira S11D, 29.I.2012, fr., A.J. Arruda et al. 555 (MG, BHCB).

Tabernaemontana $\mathrm{cf}$. linkii pode ser confundida com T. heterophylla por também apresentar fruto muricado, porém, esta apresenta heterofilia marcante e folicários alongados e não depressos ventralmente (vs. folhas iguais e frutos elipsoides depressos ventralmente). A espécie assemelha-se à $T$. linkii pela morfologia das folhas e distribuição geográfica, porém a ausência de espécimes com flores impede sua identificação inequívoca da mesma. Serra dos Carajás: Serra Sul: S11B e S11D.

Tabernaemontana linkii possui distribuição na América do Sul (Suriname, Guiana Francesa, Brasil, Peru e Bolívia) (Leeuwenberg 1994). No Brasil ocorre nas regiões Norte (AC, AM, AP, PA, RD), Nordeste (MA) (BFG 2015). Serra dos Carajás: Serra Sul, S11B e S11D, frutificando nos meses de janeiro a maio.

\section{Agradecimentos}

Agradecemos ao Museu Emílio Goeldi, a estrutura $\mathrm{e} o$ apoio fundamentais ao desenvolvimento deste trabalho. Aos curadores dos herbários consultados, o acesso ao material examinado. Ao ICMBio, especialmente ao Frederico Drumond Martins, a licença de coleta concedida a o suporte nos trabalhos em campo. Ao Aluísio Fernandes Jr, Pedro Lage Viana, Climbiê Ferreira Hall e Julia Meirelles sempre solícitos no esclarecimento de dúvidas. Ao ilustrador João Silveira, que tão bem ilustrou as espécies no presente trabalho. Ao Pedro Viana parte das fotografias que ilustraram este artigo. Ao projeto objeto do convênio MPEG/ITV/FADESP (01205.000250/2014-10) e ao projeto aprovado pelo CNPq (processo 455505/2014-4).

\section{Referências}

BFG - The Brazil Flora Group (2015) Growing Knowledge: an overview of seed plant diversity in Brazil. Rodriguésia 66: 1085-1113.

Endress ME \& Bruyns PV (2000) A revised classification of the Apocynaceae s.l. Botanical Review 66: 1-56.
Endress ME (2004) Apocynaceae: brown and now. Telopea 10: 525-541.

Endress ME, Liede-Schumann S \& Meve U (2014) An updated classification for Apocynaceae Phytotaxa 159: 175-194.

Espírito-Santo FS (2017) A Tribo Marsdenieae (Apocynaceae) para o Brasil. Tese de Doutorado, Universidade Estadual de Feira de Santana. 204p.

Fontella-Pereira J, Santos RGP, Goes MB \& CáceresMoral SA (2014) Notas taxonómicas sobre Hemipogon subgen. Astephanopsis, y descripción de un nuevo género (Apocynaceae, Asclepiadoideae, Asclepiadeae, Metastelmatinae) Bonplandia 23: 25-31.

Gomes SM (2008) Morfo-anatomia de frutos secos em espécies de Apocynaceae: significado ecológico e evolutivo, Acta Botanica Brasilica 22: 521-534.

Hansen BF (1985) A monographic revision of Forsteronia (Apocynaceae). PhD Thesis, University of South Florida, Florida. 382p.

Kinoshita LS (2005). Apocynaceae In: Wanderley MGL, Shepherd GJ, Melhem TS, Martins SE, Kirizawa M \& Giulietti AM (eds.) Flora Fanerogâmica do Estado de São Paulo. Instituto de Botânica, São Paulo. Vol. 4, pp 35-92.

Koch I \& Kinoshita LS (1999) As Apocynaceae s. str. da região de Bauru, São Paulo, Brasil. Acta Botanica Brasilica 13: 61-86.

Leeuwenberg AJM(1994)Arevision of Tabernaemontana: the New World species and Stemmadenia. Vol 2. Royal Botanical Garden Press, Kew. 450p.

Mabberley DJ (2008) Mabberley's plant book: a portable dictionary of plants, their classifications and uses. Third Edition. Cambridge University Press, Cambridge. 1021p.

Matozinhos CN \& Konno TUP (2008) Apocynaceae s.l. na Reserva Biológica da Represa do Grama, Descoberto, Minas Gerais, Brasil. Rodriguésia 59: 87-98.

Matozinhos CN \& Konno TUP (2011) Diversidade taxonômica de Apocynaceae na Serra Negra, MG, Brasil. Hoehnea 38: 569-595.

Morales JF (1999) A synopsis of the genus Odontadenia Series of revisions of Apocynaceae XL. Bulletin du Jardin botanique national de Belgique 67: 381-477

Morales JF (2005a) Estudios en las Apocynaceae Neotropicales XIII: revisión del género Temnadenia (Apocynoideae, Echiteae) Candollea 60: 207-231

Morales JF (2005b) Estudios en las Apocynaceae Neotropicales XIX: La Familia Apocynaceae s. str. (Apocynoideae, Rauvolfioideae) de Costa Rica. Darwiniana 43: 90-191.

Morales JF (2007) Estudios en las Apocynaceae Neotropicales: nuevas especies de Lacmellea (Rauvolfioideae, Willughbeeae) para Sur América. Rev. Brasileira de Botânica 30: 205-210. 
Morales JF, Endress ME \& Liede-Schumann S (2017) Sex, drugs and pupusas: disentangling relationships in Echiteae. Taxon 66: 623-644.

Morokawa R, Simões AO \& Kinoshita LS (2013) Apocynaceae s. str. do Parque Nacional da Serra da Canastra, Minas Gerais, Brasil. Rodriguésia 64: 179-199.

Pereira ASS, Simões AO \& Santos JUM (2016) Taxonomy of Aspidosperma Mart. (Apocynaceae, Rauvolfioideae) in the state of Pará, Northern Brazil. Biota Neotropica. 16: e20150080.

Rapini A (2010) Revisitando as Asclepiadoideae (Apocynaceae) da Cadeia do Espinhaço. Boletim de Botânica da Universidade de São Paulo 28: 97-123.

Sales MF (1993) Estudos taxonômicos de Mandevilla Lindl. subgênero Mandevilla (Apocynaceae) no
Brasil. Tese de Doutorado. Universidade Estadual de Campinas, Campinas. 412p.

Simões AO, Endress ME, van der Niet T, Kinoshita LS \& Conti E (2006) Is Mandevilla (Apocynaceae, Mesechiteae) Monophyletic? Evidence from five plastid DNA loci and morphology. Annals of the Missouri Botanical Garden 93: 565-591.

Spjut RW (1994) A systematic treatment of fruit types. Memoirs of the New York Botanical Garden, New York 70: 1-182.

Viana SS, Santos JUM \& Simões AO (2017) Diversidade taxonômica de Apocynaceae na ilha do Marajó, PA, Brasil. Rodriguésia 68: 623-652.

Woodson Jr. RE (1933) Studies in Apocynaceae IV The American Genera of Echitoideae. Annals of the Missouri Botanical Garden 20: 605-790.

\section{Lista de exsicatas}

Almeida TE 2497 (13.3), 2508 (13.2). Arruda AJ 295 (2.1), 313 (10.1), 555 (13.4), 752 (5.1), 1266 (13.3). Cavalcante P 2658 (3.1), 2671 (5.1), 2686 (7.1). Costa JLC 21 (7.1). Costa LV 509 (4.1), 512 (13.1), 577 (8.1), 636 (10.1), 664 (13.2), 699(12.1), 833(5.1). Daly DC 1710 (7.1), 1713 (9.1), 1976 (5.1). Falcão BF 559 (9.1). Fernandes GEA 7 (5.1), 39 (7.1) 44 (5.1), 50 (8.1), 59 (4.1), 60 (13.3), 67 (8.1), 77 (8.1), 80 (3.1), 88(3.1), 173 (11.2), 173 (11.1) 128 (7.1) 174 (7.1). Giacomin LL 1155 (13.4). Gil A 460 (7.1), 511(12.1). Giorni VT 195 (3.1), 296 (8.1). Gontijo FD 155 (13.3). Harley RM 57360 (7.2), 57385 (7.2), 57417 (7.1), 57427 (13.1), 57457 (13.1), 57485 (7.1), 57498 (5.1). Hiura AL 73 (12.1). Lobato LC 2618 (2.2), 3777 (5.1), 3778 (12.1), 3798 (7.2), 4107 (6.1), 4343 (7.2), 4398 (7.1), 4441(12.1). Marinho L 167 (10.1). Meirelles J 977 (12.1). Mota NFO 1111 (3.1) 1127(3.1), 1130 (12.1), 1144 (5.1), 1168 (13.1), 2004 (6.1). Nascimento OC 967 (7.1). Nunes CS 86(1.1). Pivari MO 1558 (3.1), 1641 (13.3). Praia TS 23 (12.1). Ribeiro RD 1387 (2.1). Rocha K 94 (7.1). Rosa NA 4499 (7.1), 4669 (12.1). Santos FMG 387 (9.1), 388 (9.1), 389 (9.1), 390 (9.1), 391 (9.1). Santos JC 1477 (10.1). Santos MR 1839 (10.1). Santos RS 30 (10.1), 169 (7.2), 170(7.1). Secco R 166 (7.1), 172 (13.3), 230 (5.1), 247 (11.2), 335 (1.1), 696 (1.1), 425 (5.1), 453 (7.2), 664 (7.1), 722 (5.1). Silva AS 18 (6.1), 41 (6.1). Silva ASL 1785 (7.1), 1863 (3.1), 1919 (5.1). Silva DF 909 (2.3), 1039 (2.2), 1045 (2.3). Silva JP (142-A) (8.2). Silva LVC 1078 (5.1). Silva MPM 52 (7.1). Silva MFF 1328 (13.3). Silva MG 2993 (7.1), 3001 (6.1). Simões AO 1807 (13.3), 1809 (4.1). Sperling CR 5637 (7.1), 5675 (7.1), 5718 (5.1), 5750 (3.1). Trindade JR 349(7.1). Vasconcelos LV 971 (8.1), 1008 (8.1). Viana PL 3791 (5.1), 4353 (4.2), 4356 (8.1), 5603 (7.1), 6196 (7.1). Vidal CV 644 (13.2). 
